\title{
Synthesis, Cytotoxic Activity, Crystal Structure, DFT Studies and Molecular Docking of 3-Amino-1-(2,5-dichlorophenyl)-8- methoxy-1H-benzo[f]chromene-2-carbonitrile
}

\author{
Menna El Gaafary ${ }^{1,2}$, Tatiana Syrovets ${ }^{2}{ }^{\circ}$, Hany M. Mohamed ${ }^{3,4}{ }^{\oplus}$, Ahmed A. Elhenawy ${ }^{4,5}{ }^{\circ}$, \\ Ahmed M. El-Agrody ${ }^{4, *}$, Abd El-Galil E. Amr $6,7, * \mathbb{D}$, Hazem A. Ghabbour ${ }^{8} \mathbb{D}$ and Abdulrahman A. Almehizia ${ }^{6} \mathbb{D}$ \\ 1 Department of Pharmacognosy, College of Pharmacy, Cairo University, Cairo 11562, Egypt; \\ mennat_elgaafary@yahoo.com \\ 2 Institute of Pharmacology of Natural Products and Clinical Pharmacology, Ulm University, \\ 89081 Ulm, Germany; tatiana.syrovets@uni-ulm.de \\ 3 Chemistry Department, Faculty of Science, Jazan University, Jazan 45142, Saudi Arabia; \\ hanysm83@yahoo.com \\ 4 Chemistry Department, Faculty of Science, Al-Azhar University, Nasr City, Cairo 11884, Egypt; \\ elhenawy_sci@hotmail.com \\ 5 Chemistry Department, Faculty of Science and Art, AlBaha University, Mukhwah, \\ Al Bahah 65731, Saudi Arabia \\ check for \\ updates \\ Citation: El Gaafary, M.; Syrovets, T.; \\ M. Mohamed, H.; A. Elhenawy, A.; M \\ El-Agrody, A.; El-Galil E. Amr, A.; \\ Ghabbour, H.A.; Almehizia, A.A. \\ 6 Pharmaceutical Chemistry Department, Drug Exploration and Development Chair (DEDC), College of \\ Pharmacy, King Saud University, Riyadh 11451, Saudi Arabia; mehizia@ksu.edu.sa \\ 7 Applied Organic Chemistry Department, National Research Centre, Dokki, Giza 12622, Egypt \\ 8 Department of Medicinal Chemistry, Faculty of Pharmacy, University of Mansoura, Mansoura 35516, Egypt; \\ ghabbourh@yahoo.com \\ * Correspondence: elagrody_am@azhar.edu.eg (A.M.E.-A.); aamr@ksu.edu.sa (A.E.-G.E.A.)
} Synthesis, Cytotoxic Activity, Crystal Structure, DFT Studies and Molecular Docking of 3-Amino-1-(2,5dichlorophenyl)-8-methoxy-1Hbenzo[f $f$ chromene-2-carbonitrile. Crystals 2021, 11, 184. https:// doi.org/10.3390/cryst11020184

Academic Editor: Alexander Y. Nazarenko

Received: 27 January 2021

Accepted: 11 February 2021

Published: 13 February 2021

Publisher's Note: MDPI stays neutral with regard to jurisdictional claims in published maps and institutional affiliations.

Copyright: (c) 2021 by the authors. Licensee MDPI, Basel, Switzerland. This article is an open access article distributed under the terms and conditions of the Creative Commons Attribution (CC BY) license (https:// creativecommons.org/licenses/by/ $4.0 /)$.

\begin{abstract}
The target compound 3-amino-1-(2,5-d ichlorophenyl)-8-methoxy-1H-benzo[f]-chromene-2carbonitrile (4) was synthesized via a reaction of 6-methoxynaphthalen-2-ol (1), 2,5-dichlorobenzaldehyde (2), and malononitrile (3) in ethanolic piperidine solution under microwave irradiation. The newly synthesized $\beta$-enaminonitrile was characterized by FT-IR, ${ }^{1} \mathrm{H} \mathrm{NMR},{ }^{13} \mathrm{C} \mathrm{NMR}$, mass spectroscopy, elemental analysis and $\mathrm{X}$-ray diffraction data. Its cytotoxic activity was evaluated against three different human cancer cell lines MDA-MB-231, A549, and MIA PaCa-2 in comparison to the positive controls etoposide and camptothecin employing the XTT cell viability assay. The analysis of the Hirshfeld surface was utilized to visualize the reliability of the crystal package. The obtained results confirmed that the tested molecule revealed promising cytotoxic activities against the three cancer cell lines. Furthermore, theoretical calculations (DFT) were carried out with the Becke3-Lee-Yang-parr (B3LYP) level using 6-311++G(d,p) basis. The optimization geometry for molecular structures was in agreement with the X-ray structure data. The HOMO-LUMO energy gap of the studied system was discussed. The intermolecular-interactions were studied through analysis of the topological-electron-density(r) using the QTAIM and NCI methods. The novel compound exhibited favorable ADMET properties and its molecular modeling analysis showed strong interaction with DNA methyltransferase 1.
\end{abstract}

Keywords: benzochromene; microwave irradiation; X-ray; cytotoxic activity; DFT molecular orbital calculations; optimization geometry; HOMO; LUMO; ADMET properties; molecular docking

\section{Introduction}

Chromene and benzochromene derivatives represent an important class of oxygencontaining heterocyclic compounds. They exhibit a wide range of biological activities, such as antimicrobial [1-4], anti-influenza virus [5] anti-proliferative [6-8], anti-inflammatory, analgesic, and selective COX-2 inhibitory activities [9] and effects. Also, the small molecules of benzochromene derivatives apply their anticancer activities by binding to DNA, thereby damaging DNA structure, changing the replication of double helix DNA, hindering the 
division of cancer cells, and binding to DNA through covalent and/or non-covalent interactions $[8,10]$. In addition, $4 H$-benzo[ $h]$ chromene derivatives are a very successful choice in the treatment of several human diseases. For instance, some derivatives of 2-amino-4-aryl-4H-benzo[ $h]$ chromene-3-carbonitrile and 2-amino- 4-aryl-6-methoxy- $4 H$ benzo[ $h]$ chromene-3-carbonitrile act as potential tumor vascular-disrupting agents and induce cell cycle arrest at G2/M and apoptosis [11,12], thus they have emerged as a new class of cytotoxic agents [13-21]. In addition, a range of studies has revealed the potential anticancer effect of $1 H$-benzo[f $f$ chromene derivatives [22-27]. Some 3-amino-1aryl- $1 H$-benzo[ $f]$ chromene-2-carbonitrile derivatives exhibit $c$-Src kinase inhibitory and antiproliferative activities [22] and show a high potency for the inhibition of hAChE [23], while inducing cell cycle arrest and apoptosis in human cancer cells via dual inhibition of topoisomerase I and II [26,27]. In continuation of our previous work in benzochromenes chemistry $[2-4,22,26,27]$ and the study of crystal structure for benzochromene derivatives [2,28-34], we report the synthesis, NMR spectra, crystal structure, theoretical calculations (DFT), molecular modeling analyses, and cytotoxic activity of 3-amino-1-(2,5dichlorophenyl)-8-1H-benzo[f]chromene-2-carbonitrile.

\section{Results and Discussion}

\subsection{Chemistry}

The preparation of the heterocyclic derivative is cited in (Scheme 1). Multi-component reaction of 6-methoxynaphthalen-2-ol (1) with 2,5-dichlorobenzaldehyde (2) and malononitrile (3) in ethanolic piperidine $(25 \mathrm{~mL} / 0.5 \mathrm{~mL})$ solution under microwave irradiation for 2 min at $140{ }^{\circ} \mathrm{C}$ provide 3-amino-1-(2,5-dichlorophenyl)- 8-methoxy- $1 \mathrm{H}$-benzo[f $]$ chromene-2carbonitrile (4). The maximum power of microwave irradiation was optimized by repeating the reaction at different powers $(200,300$, and $400 \mathrm{~W})$ and for periods of time $(1,1.5$, and $2 \mathrm{~min}$ ). The optimum condition was obtained by using microwave irradiation at $400 \mathrm{~W}$ and a reaction time of $2 \mathrm{~min}$, which gave the highest yield of the desired compound. It is also important to note that the 1-position of compound 4 is a chiral center and the reaction was controlled using the TLC technique. The optical activity of the target compound 4 was measured using a Carl Zeiss polarimeter. The results indicated that compound 4 has zero rotation (i.e., it is optically inactive) and thus it is in the form of a racemic ( \pm ) mixture [27], as illustrated in (Scheme 1).<smiles>COc1ccc2cc(O)ccc2c1</smiles>

(1)<smiles>O=Cc1cc(Cl)ccc1Cl</smiles>

(2)

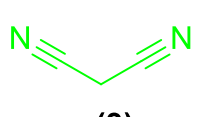

(3)

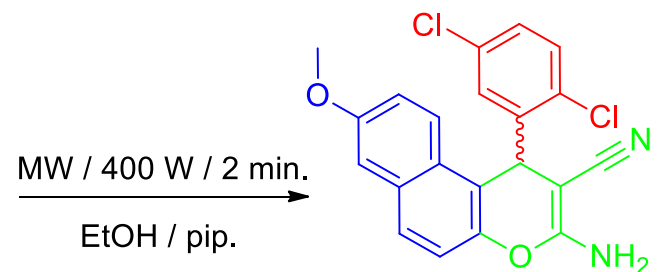

(4)

Scheme 1. Synthesis of 3-amino-1-(2,5-dichlorophenyl)-8-methoxy-1H-benzo[f]chromene-2-carbonitrile (4).

\subsection{Spectroscopic Data}

The structure was studied using spectral data. The IR spectrum of compound 4 confirmed the presence of the characteristic $\mathrm{NH}_{2}$ absorption bands at $v 3450,3337,3213 \mathrm{~cm}^{-1}$, and $\mathrm{CN}$ absorption band at $v 21 \mathrm{~cm}^{-1}$. On the other hand, the ${ }^{1} \mathrm{H}$ NMR spectrum of 4 showed the singlet signals of the amino, methine, and methoxy protons at $\delta 7.07, \delta 5.74$, and $\delta 3.83 \mathrm{ppm}$, respectively. The ${ }^{13} \mathrm{C}$ NMR spectrum of 4 showed signals resonating at $\delta 55.21$ and $\delta 36.23$ ppm which were attributable to the methoxy and methine carbons. Furthermore, the mass spectrum, elemental analysis, and the single crystal X-ray analysis gave an absolute confirmation for structure 4 . 


\subsection{Cell Viability Assay}

Cytotoxic activity of the newly synthesized 3-amino-1-(2,5-dichlorophenyl)-8- methoxy$1 H$-benzo[f $]$ chromene-2-carbonitrile (compound 4 ) was examined in three human cancer cell lines, namely, the triple negative breast cancer (TNBC) MDA-MB-231, the non-small cell lung cancer (NSCLC) A549, and the pancreatic adenocarcinoma MIA PaCa-2 using the sodium 3'-[1-(phenylaminocarbonyl)-3,4-tetrazolium]-bis (4-methoxy-6- nitro)-benzene sulfonic acid hydrate (XTT) colorimetric assay [35,36]. Camptothecin and etoposide were included in the experiments as reference cytotoxic drugs. The results were shown in Table 1 and Figure 1.

Table 1. Cytotoxic activity of the target compound 4 against MDA-MB-231, A549, and MIA PaCa-2 cell lines.<smiles>COc1ccc2c3c(ccc2c1)OC(N)=C(C#N)C3Br</smiles>

(4)

\begin{tabular}{|c|c|c|c|c|}
\hline \multirow[t]{2}{*}{ Compound } & \multirow[t]{2}{*}{ Ar } & \multicolumn{3}{|c|}{$\begin{array}{c}\text { Cell Lines } \\
\mathrm{IC}_{50}(\mu \mathrm{M})^{\mathrm{a}} 24 \mathrm{~h}\end{array}$} \\
\hline & & MDA-MB-231 & A549 & MIA РaCa-2 \\
\hline 4 & $2,5-\mathrm{Cl}_{2} \mathrm{C}_{6} \mathrm{H}_{3}$ & $10.7 \pm 1.5$ & $7.7 \pm 0.7$ & $7.3 \pm 0.7$ \\
\hline Etoposide & - & $>30$ & $>30$ & $>30$ \\
\hline Camptothecin & - & $22.4 \pm 20.6$ & $20.0 \pm 10.2$ & $0.9 \pm 0.02$ \\
\hline
\end{tabular}

${ }^{\mathrm{a}} \mathrm{IC}_{50}$ values expressed in $\mu \mathrm{M}$ as the mean values of triplicate wells from at least three experiments and are reported as the mean \pm standard error.

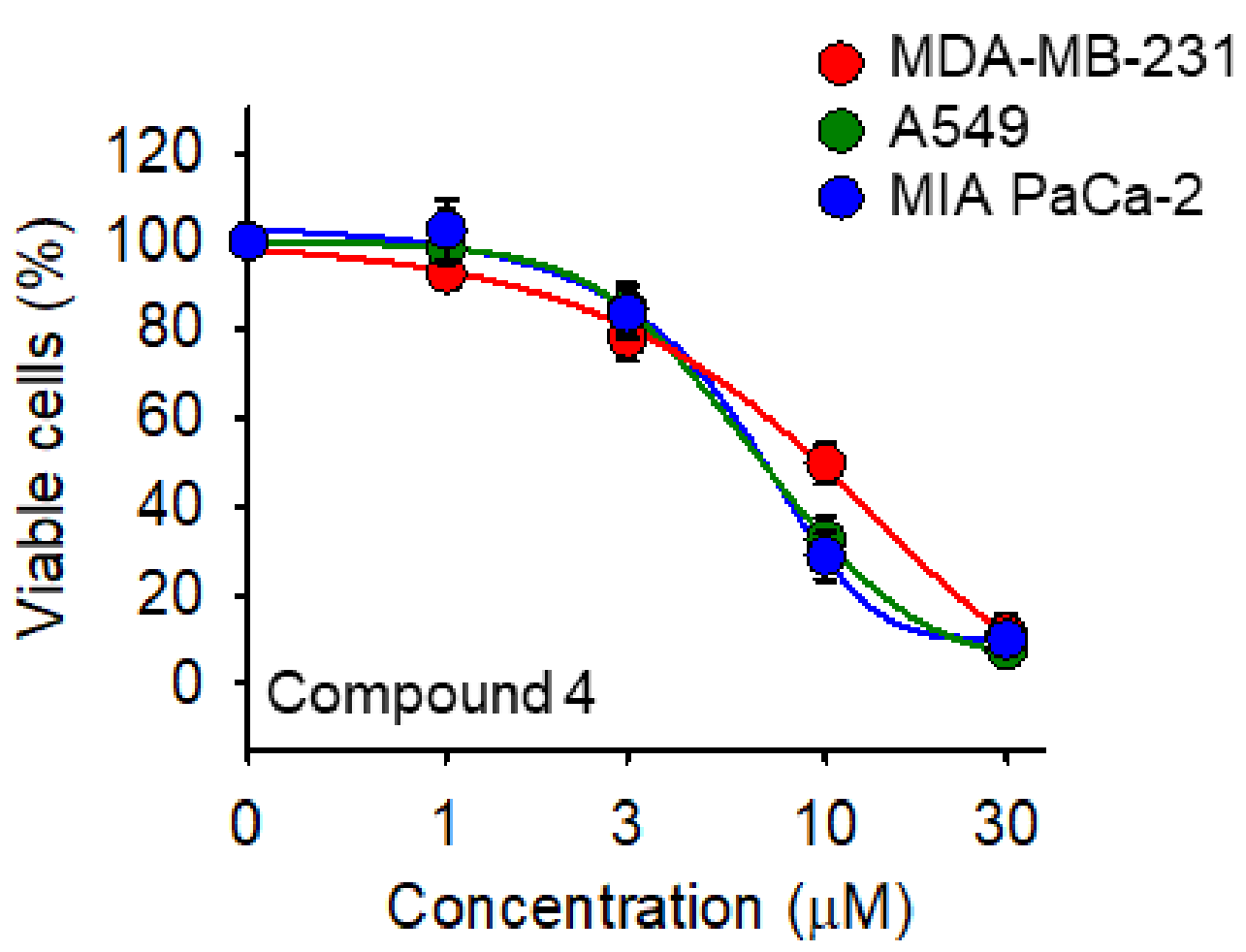

Figure 1. $\mathrm{IC}_{50}$ values expressed in $(\mu \mathrm{M})$ of compound 4 against MDA-MB-231, A549, and MIA PaCa-2 tumor cells. 
Table 1 indicates that the target compound 4 displayed a promising cytotoxic activity against the tested cancer cell lines. Investigations of the cytotoxic activity against MDAMB-231, A549, and MIA PaCa-2 indicated that compound 4 has $\mathrm{IC}_{50}$ values of $10.7 \mu \mathrm{M}$, $7.7 \mu \mathrm{M}$, and $7.3 \mu \mathrm{M}$, respectively. Etoposide, a known chemotherapy medication, which is used for the treatment of a number of types of cancer, did not show any sign of toxicity at the used concentrations range. On the other hand, camptothecin, the known antitumor agent, showed $\mathrm{IC}_{50}$ values of $22.4 \mu \mathrm{M}, 20.0 \mu \mathrm{M}$, and $0.9 \mu \mathrm{M}$, for MDA-MB-231, A549, and MIA PaCa-2, respectively. Finally, grafting a lipophilic electron withdrawing substituent (chlorine atoms) in 2,5-postion of the phenyl ring at 1-postion of the $1 H$-benzo[f]chromene moiety could be beneficial.

\subsection{Crystal Data}

In the compound $4, \mathrm{C}_{21} \mathrm{H}_{14} \mathrm{Cl}_{2} \mathrm{~N}_{2} \mathrm{O}_{2}$, the crystallographic data and refinement information are summarized in Table 2 . The selected bond lengths and bond angles are listed in Table 3. The asymmetric unit contains one independent molecule as shown in Figure 2. All bond lengths and angles are in normal ranges [37], the dichlorophenyl moiety makes a plane which is perpendicular with the plane of $1 H$-benzo[f]chromene moiety, with the dihedral angle equal to $89.33^{\circ}$. In the crystal packing, Figure 3, the molecules are linked via three intermolecular hydrogen bonds along the c axis Table 4. Generally, the dichlorophenyl and $1 H$-benzo $[f]$ chromene rings are connected by $\mathrm{C} 3-\mathrm{C} 14$ bond. The mean of plane passing through the $1 H$-benzo[f]chromene forms an 89.33 angle with the dichlorophenyl. This indicates the appearance of some twisting between two of the fragments (Figure 1). The cyano and amino groups located in the plane with a $1 H$-benzo[f]chromene fragment form strong molecular intra $\mathrm{H}$-bond interaction with a length of $0.85 \AA$, and dihedral bond of 165 , as seen in Table 4 . The bond lengths for the $\mathrm{C}-\mathrm{O}, \mathrm{C}-\mathrm{N}$, and $\mathrm{C}-\mathrm{Cl}$ fell within the ranges of 1.357(3)-1.395(3), 1.336(4), and 1.734(3)-1.740(3) A, respectively. Additionally, the length of $\mathrm{CN}$ is $1.140(4) \AA$ due to formation of the strong H-bonds with the neighbor molecule. The three of 4 particles were packed in the three dimensions in the asymmetric unit and showed a intermolecular $\mathrm{H}$-bond via $\mathrm{CN} \bullet \bullet-H N$ with a distance of $2.60 \AA$, as shown in Figure 3. These three molecules were structurally identical and were further linked together by two intermolecular $\mathrm{H}$-bonds as $\mathrm{N}-\mathrm{H} \bullet \bullet \bullet \mathrm{OCH}_{3}(2.52 \AA)$ and one $\mathrm{CN} \bullet \bullet \bullet \mathrm{H}$ via C7 in $1 H$-benzo[f]chromene (with a contact distance of $2.60 \AA ̊ ̊)$ ). This is of interest when using two $\mathrm{H}$-bonds via $\mathrm{Cl} \bullet \bullet \bullet \mathrm{H} \mathrm{N}$ and $\mathrm{Cl} \bullet \bullet \bullet \mathrm{OCH}_{3}$. The later $\mathrm{H}$-bonds are responsible in the crystal packing shown in Figure 3 and Table 4.

Fingerprint Plots for the Hirshfeld Surface

Hirshfeld surface analysis (HFS) is a fingerprint plot. It is a powerful map for exploring the sites that have intermolecular non-bonding interactions between the adjacent molecular groups in crystal packing [38]. The HFSs for the compound 4 have been figured out via a "d norm" descriptor, which clarifies two aspects: (i) " $\mathrm{d} e$ " is the distance between any surface-point adjacent to the interior-atom, (ii) " $\mathrm{d} i$ " illustrates the distance between the surface-point closest to the external atom. That is represented equationally as $\left(d_{\text {norm }}=\left(d_{\mathrm{i}}\right.\right.$ $\left.\left.-r^{\mathrm{vdW}_{i}}\right) / r^{\mathrm{vdW}}+\left(d_{\mathrm{e}}-r^{\mathrm{vdW}} \mathrm{e}\right) / r^{\mathrm{vdW}} \mathrm{e}\right)$ based on the Van der Waals ratio of the atom, which is also another important parameter for representing HFS [39]. The $r^{\mathrm{vdW}}{ }_{\mathrm{i}}$ and $r^{\mathrm{vdW}}$ e refer to Van der Waals' radii of the adjacent two interior and exterior atoms via the molecular

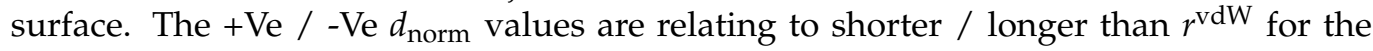
intermolecular contacts, respectively.

Crystal explorer [40] was applied to get a 3D-map and 2D-histogram (de Vs di) of the HFS for 4 molecules in Figure 4 (see also Figure S4 and Table S1 as shown in the Supplementary Materials).

The molecular HFS was plotted over the $\mathrm{d}_{\text {norm }}, \mathrm{d}_{i}, \mathrm{~d}_{e}$, shape-index, and curvedness in value ranges ( -0.9779 to 1.02128$) \AA$, (2.0284 to 5.3629$) \AA,(-1.9848$ to -1.0000$) \AA$, and ( -4.2169 to 4.000$)$, respectively, and illustrated in Figure S4 (Supplementary Materials). The HFSs for the compound 4 depicted the halogen-halogen interactions (as red spick zone; 
$\left.\mathrm{d}_{\text {norm }}\right)$, in Figure 4 . The $d_{\text {norm }}$ fingerprint map represents the presences of the strong H-bond interactions as $(\mathrm{N} \cdots \mathrm{H} / \mathrm{H} \cdots \mathrm{N})$ and $(\mathrm{N}-\mathrm{H} \cdots \mathrm{O})$ between the amino group with methoxy and the cyano group. These $\mathrm{H}$-bond interactions were marked by bright red as little spikes located on the concave side of the di fingerprint map shown in Figure 4. The $(\mathrm{N} \cdots \mathrm{H} / \mathrm{H} \cdots \mathrm{N})$ and $\mathrm{O} \cdots \mathrm{H}$ intermolecular interactions contribute to the crystal packing by $50 \%$ and $27 \%$, respectively (Figure S4; Supplementary Materials). From the analysis, the concave areas in curvedness and shape-index in Figure 4 can determine the presence of little stacking $\pi \cdots \pi$ interactions. The most sensitive indicator to any variation in morphology of the structure is the shape index. The red triangles (concave zone) located at the upper plane of a particle indicate dichlorophenyl outside the surface, while the blue triangles representing the benzo[ $f]$ chromene ring are located in internal surface. Thus, an insignificant contributionpercentage for $\mathrm{C} \cdots \mathrm{C}(2 \%)$ is located by HFS in Figure 4 . The data were obtained from the shape index in agreement with a 2D plot-fingerprint (Figure S4; Supplementary Materials). The curvedness map was used to measure the surface shape for the particles. The surface with flat sites refers to minimum values for curvedness, whereas the sharpness curvature zones reflected the large curvedness values. Consequently, splitting the surface into two patches, which tend to the interactions, occurs between adjacent particles. The large flat areas which are outlined by red mean areas lacking stacking $\pi \cdots \pi$ interactions with a contribution $\%=2 \%$ [39].

Table 2. Crystal data and structure refinement parameters for compound 4.

\begin{tabular}{|c|c|}
\hline Crystal Data & \\
\hline Chemical formula & $\mathrm{C}_{21} \mathrm{H}_{14} \mathrm{Cl}_{2} \mathrm{~N}_{2} \mathrm{O}_{2}$ \\
\hline Formula weight & 397.24 \\
\hline Crystal system, space group & Orthorhombic, Pbca \\
\hline Temperature (K) & 293 \\
\hline$a, b, c(\AA)$ & $9.3186(5), 19.0894(10), 20.7892(12)$ \\
\hline V (̊̊3) & $3698.1(3)$ \\
\hline $\mathrm{Z}$ & 8 \\
\hline Radiation type & Mo K $\alpha$ \\
\hline$\mu\left(\mathrm{mm}^{-1}\right)$ & 0.37 \\
\hline Crystal size $(\mathrm{mm})$ & $0.32 \times 0.27 \times 0.25$ \\
\hline \multicolumn{2}{|l|}{ Data collection } \\
\hline Diffractometer & Bruker APEX-II D8 venture diffractometer \\
\hline Absorption correction & Multi-scan, SADABS Bruker 2018 \\
\hline Tmin, Tmax & $0.932,0.944$ \\
\hline $\begin{array}{l}\text { No. of measured, independent and observed } \\
\qquad[\mathrm{I}>2 \sigma(\mathrm{I})] \text { reflections }\end{array}$ & $62944,4248,3181$ \\
\hline Rint & 0.049 \\
\hline \multicolumn{2}{|l|}{ Refinement } \\
\hline $\mathrm{R}[\mathrm{F} 2>2 \sigma(\mathrm{F} 2)], \mathrm{wR}(\mathrm{F} 2), \mathrm{S}$ & $0.059,0.170,1.05$ \\
\hline No. of reflections & 4248 \\
\hline No. of parameters & 253 \\
\hline No. of restraints & 0 \\
\hline $\mathrm{H}$-atom treatment & $\begin{array}{l}\text { H atoms treated by a mixture of independent } \\
\text { and constrained refinement }\end{array}$ \\
\hline$\Delta \rho \max , \Delta \rho \min \left(\mathrm{e} \AA^{-3}\right)$ & $0.91,-0.73$ \\
\hline
\end{tabular}


Table 3. Selected bond lengths ( $\mathrm{A})$, angles (०), and theoretical calculations for the title compound.

\begin{tabular}{|c|c|c|c|c|c|}
\hline $\begin{array}{l}\text { Bond } \\
\text { Lengths }\end{array}$ & $\begin{array}{l}\text { X-ray } \\
\text { Crystal }\end{array}$ & $\begin{array}{c}\text { DFT }^{*} \\
6-311++G(d, p)\end{array}$ & $\begin{array}{l}\text { Bond } \\
\text { Lengths }\end{array}$ & $\begin{array}{l}\text { X-ray } \\
\text { Crystal }\end{array}$ & $\begin{array}{c}\text { DFT }^{*} \\
6-311++G(d, p)\end{array}$ \\
\hline $\mathrm{Cl} 1-\mathrm{C} 16$ & $1.740(3)$ & 1.832 & $\mathrm{O} 2-\mathrm{C} 8$ & $1.373(3)$ & 1.411 \\
\hline $\mathrm{Cl} 2-\mathrm{C} 19$ & $1.734(3)$ & 1.845 & $\mathrm{O} 2-\mathrm{C} 21$ & $1.411(4)$ & 1.470 \\
\hline $\mathrm{O} 1-\mathrm{C} 1$ & $1.357(3)$ & 1.384 & $\mathrm{~N} 1-\mathrm{C} 1$ & $1.336(4)$ & 1.361 \\
\hline $\mathrm{O} 1-\mathrm{C} 13$ & $1.395(3)$ & 1.419 & $\mathrm{~N} 2-\mathrm{C} 20$ & $1.140(4)$ & 1.173 \\
\hline Bond & X-ray & DFT $^{*}$ & Bond & X-ray & DFT $^{*}$ \\
\hline Angles & Crystal & $6-311++G(d, p)$ & Angles & Crystal & $6-311++G(d, p)$ \\
\hline $\mathrm{C} 1-\mathrm{O} 1-\mathrm{C} 13$ & $118.33(19)$ & 119.38 & $\mathrm{O} 1-\mathrm{C} 13-\mathrm{C} 4$ & $123.1(2)$ & 122.36 \\
\hline $\mathrm{C} 8-\mathrm{O} 2-\mathrm{C} 21$ & $117.7(2)$ & 114.80 & $\mathrm{O} 1-\mathrm{C} 13-\mathrm{C} 12$ & $113.8(2)$ & 11.6 .97 \\
\hline $\mathrm{O} 1-\mathrm{C} 1-\mathrm{N} 1$ & $110.7(2)$ & 110.8 & $\mathrm{Cl1}-\mathrm{C} 16-\mathrm{C} 15$ & $118.7(2)$ & 1180.66 \\
\hline $\mathrm{O} 1-\mathrm{C} 1-\mathrm{C} 2$ & $122.4(2)$ & 122.23 & $\mathrm{Cl1}-\mathrm{C} 16-\mathrm{C} 17$ & $120.0(2)$ & 119.10 \\
\hline $\mathrm{N} 1-\mathrm{C} 1-\mathrm{C} 2$ & $126.9(3)$ & 127.21 & $\mathrm{Cl} 2-\mathrm{C} 19-\mathrm{C} 14$ & $120.8(3)$ & 120.77 \\
\hline $\mathrm{O} 2-\mathrm{C} 8-\mathrm{C} 7$ & $114.1(2)$ & 119.91 & $\mathrm{Cl} 2-\mathrm{C} 19-\mathrm{C} 18$ & $118.2(2)$ & 11631 \\
\hline $\mathrm{O} 2-\mathrm{C} 8-\mathrm{C} 9$ & $125.3(2)$ & 119.67 & $\mathrm{~N} 2-\mathrm{C} 20-\mathrm{C} 2$ & $179.3(3)$ & 178.66 \\
\hline
\end{tabular}

${ }^{*}$ Calculated bond lengths $(\AA)$, angles $\left(^{\circ}\right)$ at DFT using $6-311++G(d, p)$ basis set.

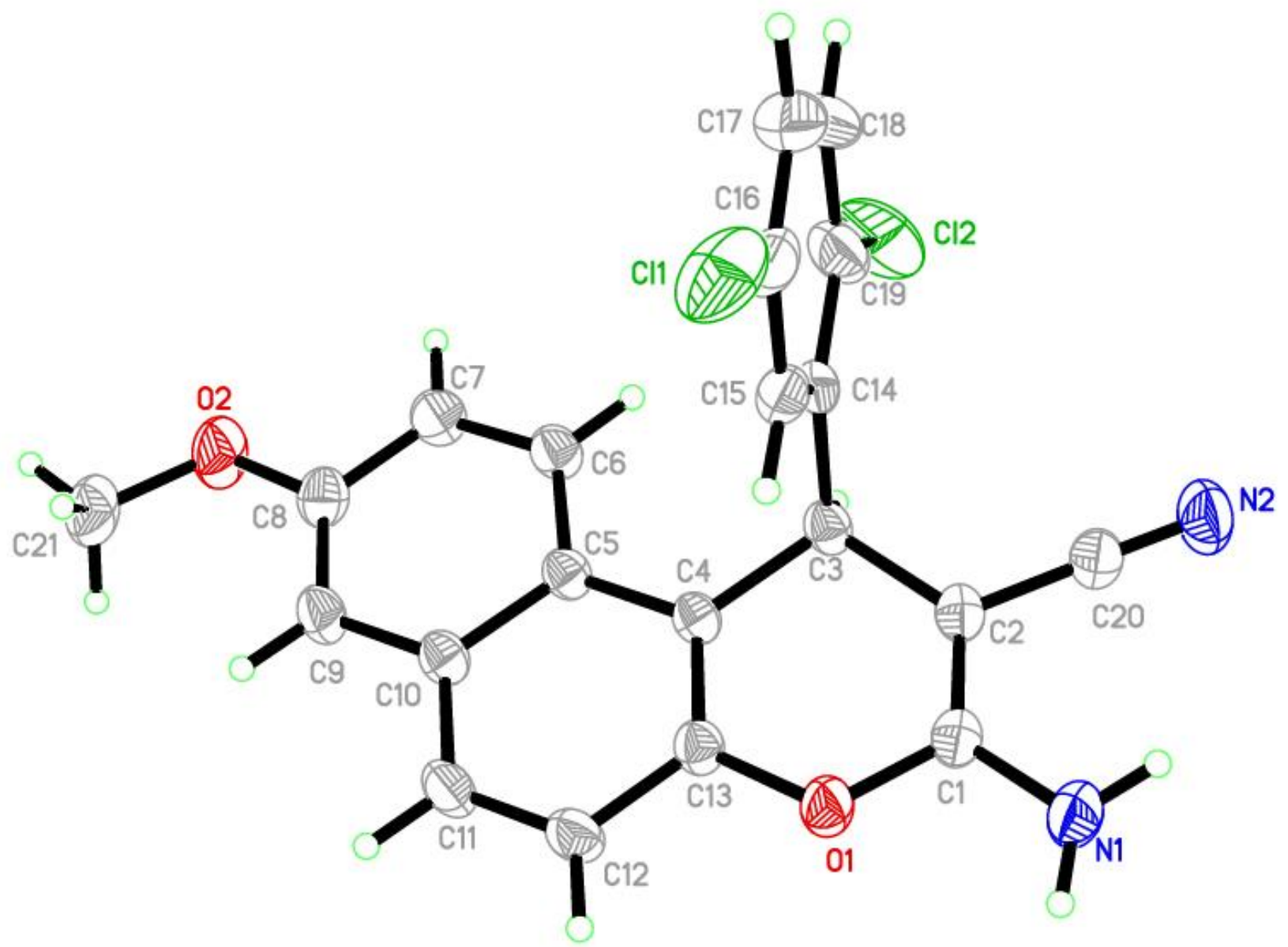

Figure 2. ORTEP diagram of the titled compound. Displacement ellipsoids are plotted at the $40 \%$ probability level for non-H atoms. 


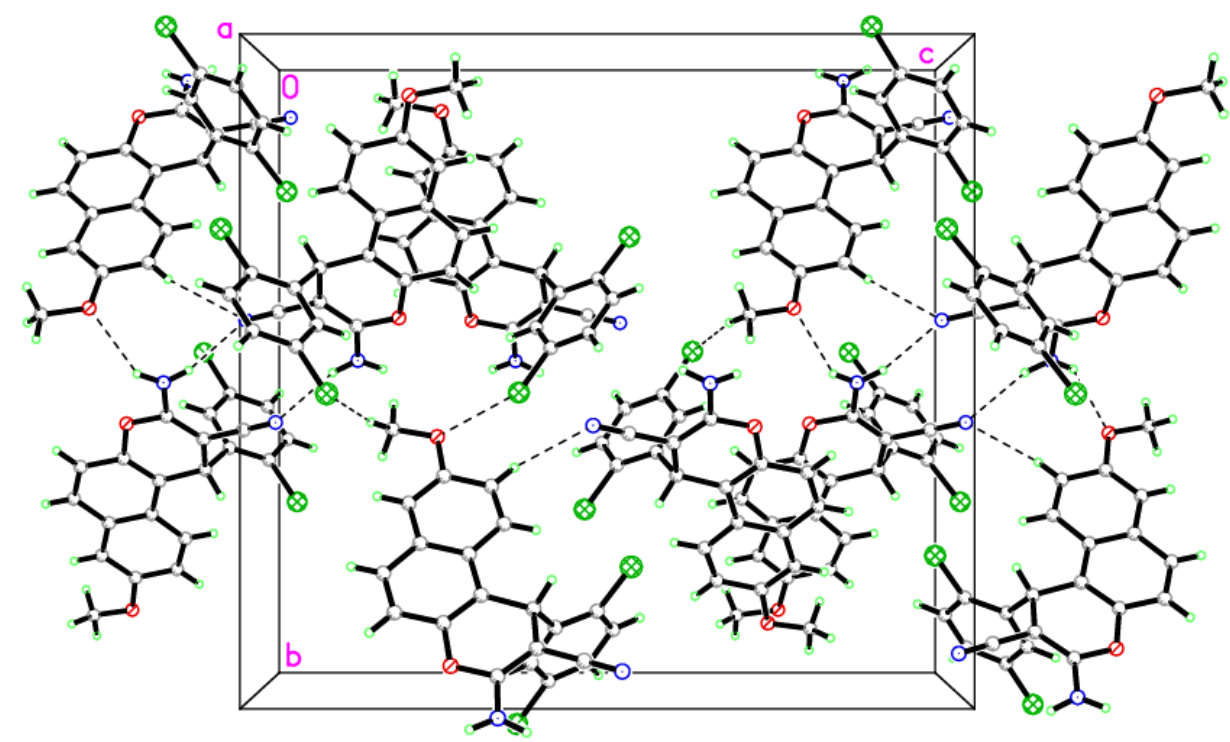

Figure 3. Molecular packing of compound 4 viewed hydrogen bonds, which are drawn as dashed lines along the $c$ axis.

Table 4. Hydrogen-bond geometry $\left(\AA{ }^{\circ}{ }^{\circ}\right.$.

\begin{tabular}{ccccc}
\hline $\boldsymbol{D}-\mathbf{H} \cdots \boldsymbol{A}$ & $\boldsymbol{D}-\mathbf{H}$ & $\mathbf{H} \cdots \boldsymbol{A}$ & $\boldsymbol{D} \cdots \mathbf{A}$ & $\boldsymbol{D}-\mathbf{H} \cdots \boldsymbol{A}$ \\
\hline $\mathrm{N} 1-\mathrm{H} 2 \mathrm{~N} 1 \cdots \mathrm{O} 2^{\text {i }}$ & $0.84(3)$ & $2.52(3)$ & $3.247(4)$ & $146(3)$ \\
$\mathrm{N} 1-\mathrm{H} 1 \mathrm{~N} 1 \cdots \mathrm{N} 2^{\text {ii }}$ & $0.85(4)$ & $2.31(4)$ & $3.145(4)$ & $165(3)$ \\
$\mathrm{C} 7-\mathrm{H} 7 \mathrm{\cdots} \cdots \mathrm{N}{ }^{\text {iii }}$ & 0.93 & 2.60 & $3.369(4)$ & 141.0 \\
\hline
\end{tabular}

Symmetry codes: (i) $-x+1 / 2, y+1 / 2, z$; (ii) $-x,-y+1,-z+1$; (iii) $x+1 / 2,-y+1 / 2,-z+1$.

$\mathrm{d} i$

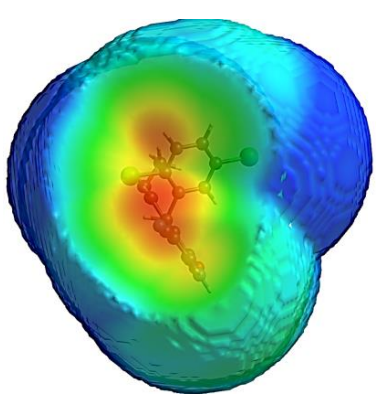

Shape index

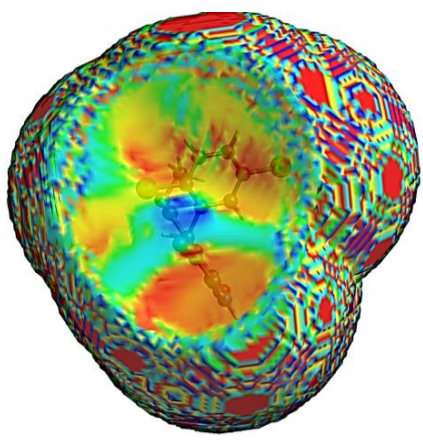

$\mathrm{D} e$

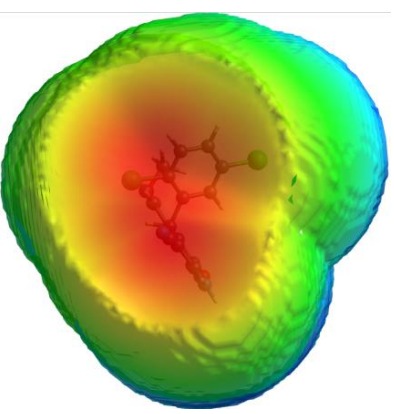

Curvedness

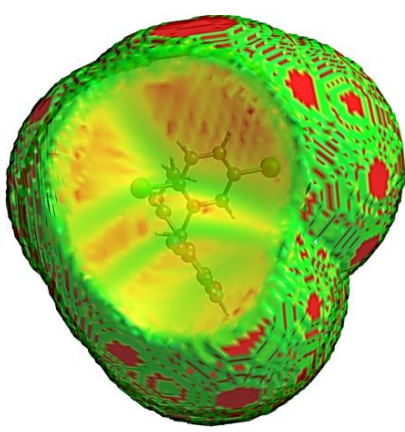

d norm

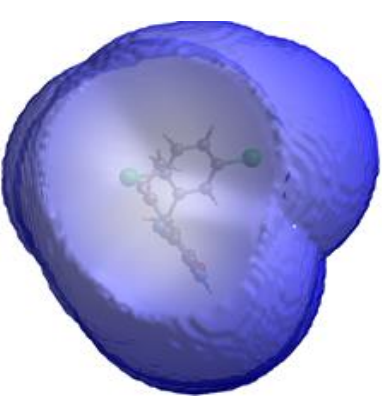

Percentage contacts

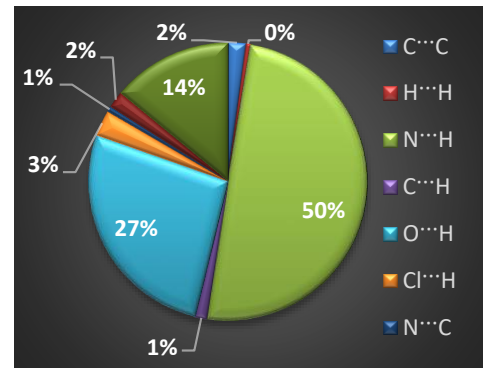

Figure 4. Molecular hirshfeld fingerprints $d_{n o r m}$, $\mathrm{i}$, de, shape index, and curvedness and possible percentage contacts in compound 4 . 


\subsection{Molecular DFT Studies}

\subsubsection{Geometry Optimization}

All computational simulations for compound 4 have been calculated in DFT with a B3LYP $/ 6-311++G(d, p)$ basis set. Optimization of the structural geometry for ligand was compared via the X-ray model structure shown in Table S2, Figure S5 (Supplementary Materials). For the obtained data in Table S2, one can reveal good agreement between the calculated optimization parameters.

\subsubsection{Analysis of Frontier Molecular Orbital}

Frontier molecular orbitals (FMOs) through two types of HOMO (donating electron) and LUMO (accepting electron) are crucial orbitals for a molecule. These orbitals were able to display the binding manner of a biomolecule with a receptor. The FMOs gap was characterized by the chemical reactivity and kinetic stability of the molecule [41-43]. The molecule 4 has $E_{H O M O}(-0.218$ Hatree $=-5.947 \mathrm{eV})$ with $\mathrm{E}_{L U M O}(-0.08780$ Hatree $=$ $-2.389 \mathrm{eV}$ ) which reflects the strength ability of the molecule for donating electron to biological media [41]. HOMO and LUMO areas had capped $1 H$-benzo[f]chromene-2carbonitrile, as shown in Figure 5. These data elucidate the intramolecular charge transfer through which $H O M O \rightarrow L U M O$ takes place.
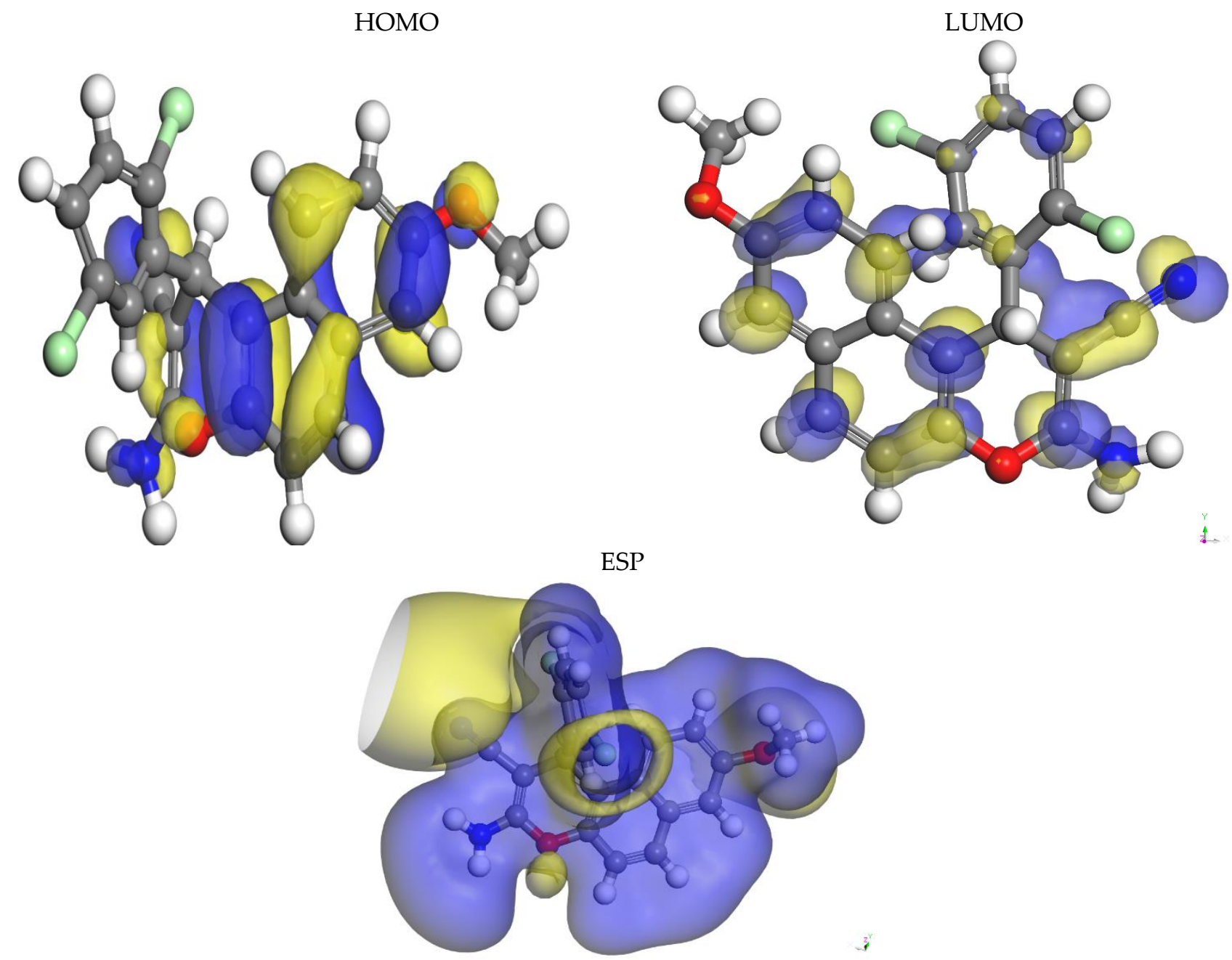

Figure 5. Plotting the HOMO, LUMO molecular orbitals, and MEP for the most stable optimization geometry of compound 4 based on B3LYP/6-311++G(d,p). 


\subsubsection{Chemical Reactivity}

Chemical reactivity reflects the modification possibility for the molecular system during chemical and biochemical reactions. The increased energy of the FMOs (E-FMOs) has been linked to the soft nucleophiles and the hard electrophiles. $\Delta \mathrm{G}$ was used as a measure of the stability index. The molecule with a small $\Delta \mathrm{G}$ exhibits high polarizability and softness, hence raising the chemical reactivity and nucleophilicity (easy donation of an electron to an acceptor of biological media), with vice versa. Furthermore, stabilization interaction is conversely related to $\Delta \mathrm{G}$ [43]. Thus, we studied the electrophiles and nucleophiles depending on softness and hardness concepts. The stability and reactivity of the molecular system were predicted by global reactivity parameters such as " $\mathrm{S}$ " softness (it measures stability of molecules and is directly proportional with chemical reactivity) [44]. " $\eta$ " hardness (reciprocal of softness), $\mu$ (chemical potential), $\chi$ (electronegativity) [41], $\mu^{-}$ (donating power of electron), $\mu^{+}$(catching electron efficiency), and wi (Electrophilicity index) estimated reducing energy, which resulted from the maximal electrons current transfer between the donor and the acceptor [45]. These restrictions were demonstrated in both terms I (ionization potential) and A (electron affinity) [45]. The charge transfer has been examined through the reactivity index term, which measured stabilization energy for the media during chemical reactions when it is gaining a maximum amount of the electrons $\left(\Delta N_{\max }\right)$ from the environment. The variation in binding energy at the ground state is computed using the maximal $\left(\Delta E_{\max }\right)$ and minimal $\left(\Delta E_{\min }\right)$ electrons transfer terms shown in Table 5.

Table 5. Calculated energetic global reactivity parameters for compound 4 at DFT with B3LYP/6-311++G(d,p) basics sets.

\begin{tabular}{|c|c|c|c|c|c|c|c|c|c|c|c|c|c|}
\hline HOMO & LUMO & $\Delta \mathrm{G}$ & I & A & $\eta$ & $\mathbf{S}$ & $x$ & $\omega \mathrm{i}$ & $\mu^{+}$ & $\mu^{-}$ & $\Delta N_{\max }$ & $\Delta E_{\max }$ & $\Delta E_{\min }$ \\
\hline-5.947 & -2.389 & -3.558 & 5.947 & 2.389 & 1.779 & 0.562 & -4.168 & 4.882 & -3.278 & -5.057 & -1.171 & -4.685 & -2.342 \\
\hline
\end{tabular}

The obtained data showed that the low $\Delta G$ value promoted increasing most chemical descriptors ( $\mathrm{S}, \chi, \omega \mathrm{i} ; \mu^{+}, \mu^{-}, \mu, \Delta N_{\max }, \Delta E_{\min }$, and $\Delta E_{\max }$ ), as seen in Table 5 . These results reflect the higher reactivity for compound 4 against biological media. The compound 4 transfers an amount of electrons $\left(\Delta N_{\max }=-1.71\right)$ with significant stability $\left(\Delta E_{\max }=-4.68\right.$ and $\left.\Delta E_{\min }=-2.34\right)$ when interacting with a bioreceptor.

Local descriptors describe the variation in the electronic system that is represented as: $\vec{F}$ "Fukui function". The more reactive center in a chemical species has a high value of $F_{\kappa}^{+}$due to the deformation of the electronic density at a specific site toward accepting or donating the electron $[46,47]$. These parameters were calculated as reported previously [48]. The highest $F_{\kappa}^{-}$value has been over C18 and C24 (Table S4; Supplementary Materials). Thus, these atoms are the most sensitive regions against electrophilic attack. In case of the $F_{\kappa}^{+}$, negative charge has been transferred in between C18 and C17 in the same ring.

\subsubsection{Analysis of the MEP Surface}

The molecular electrostatic potential (MEP) map was initially performed to investigate the sensitivity of molecular sites toward electrophilic and nucleophilic attacks [47,49-52]. MEP figures the electrons distribution on the reactive molecular sites, predicting the interaction manner of the molecule as well as physiochemical descriptors relationships $[53,54]$. Furthermore, MEP introduces a balance between both repulsive interaction of the nuclei (positive charge as nucleophilic reactivity in blue color) and attractive interaction of the electrons (negative charge as electrophilic potency in yellow and red colors). The gray color is visualized as an intermediate potential value. The variation in colors on MEPs exhibits the difference in electrostatic potential values, which increases in the order gray < yellow < blue, as shown in Figure 5. The highest negative area covered the $\mathrm{N}$ atom for $\mathrm{CN}$ group. The electron density covering $\mathrm{O}$ of $\mathrm{OCH}_{3}$ group was higher than those covering $\mathrm{O}$ in the chromene ring seen in Figure 5. That reflects the high sensitivity for these sites to electrostatic attacks with the receptor. The maximum positive region shielded most 
rings. These regions provided one with knowledge about which molecular sites can form intermolecular interactions. Furthermore, raising the blue region may be explained by a high electrophilic potency, which is responsible for recognizing this compound against a binding site for the receptor through electrostatic interactions between the substrate and the receptor.

\subsubsection{QTAIM, NCI and ELF Approaches}

The AIM "atoms in molecule theory" was utilized routinely to assess H-bond formation [55]. QTAIM "Bader's quantum theory of atoms" was applied using AIMAll [56], to detect the contribution of the intramolecular-forces of the molecular conformation inside the studied systems. The topological analysis of the electron density $\rho(r)$ for compound 4 was performed based on Bond-Critical-Points (BCPs, as green dots) and Ring-CriticalPoints (RCPs, red dots) represented in Figure 6A. The weak intramolecular interaction was identified at $\mathrm{C} 21-\mathrm{H} 37 \ldots \mathrm{O} 26$ and $\mathrm{C} 14-\mathrm{H} 39 . . \mathrm{O} 24$ with the calculated Hbond energies varying from -0.08 to $-0.05 \mathrm{kcal} \mathrm{mol}^{-1}$, respectively. The QTAIM analysis is not sufficient for examining the supposed weak " $\mathrm{NCI}$ " non-covalent-interactions, especially involving intramolecular hydrogen bonds [57]. Thus, the NCI approach [58,59] was additionally applied using Multiwfn [60]. The reduced-density-gradient " $s(r)$ " isosurface was examined at a gradient surface corresponding to $s=0.1$ a.u., then the corresponding plots were generated in Figure 6B. The weak attractive NCIs were indicated between both phenyl rings as represented by Broad multiform domains, whereas small domains correspond to the strongest hydrogen bonds identified in the studied compounds. Delocalized electrons of aromatic groups are represented by the egg-shape domains, as shown in Figure 6B. Furthermore, we decided to study the electronic structure of compound 4 through utilizing the topological analysis of the electron localization function "ELF" based on the valence basin populations and plotted in Figure 6C. ELF topological analysis shows the atomic basin population changes along the backbone of compound to stabilize the crystal package.

The reduced density gradient (RDG) was plotted versus the electron density multiplied by the sign of the second Hessian eigenvalue (Figure S6; Supplementary Materials). The domains-shape is correlated with the interaction-power. The Broad disk-shaped domains indicate weak attractive $\left(\lambda_{2}<0\right)$ and repulsive $\left(\lambda_{2}>0\right)$ interactions. Gradient surfaces correspond to $s=0.1 \mathrm{a} . \mathrm{u}$. The observed attractive and repulsive contacts are in equilibrium, allowing two aromatic fragments to maintain the defined mutual orientation.

\subsubsection{NMR Spectra}

The absolute isotropic chemical shielding was calculated for 4 using the same quantum level. Then relative chemical shifts were investigated [61] using the corresponding TMS shielding $\left(\sigma_{\text {cal }}\right)$. The chemical shifts were calculated numerically by $\delta_{\text {cal }}=\sigma_{\text {cal }}(\mathrm{TMS})-\sigma_{\text {cal }}$. The obtained experimental values are provided in Table S5 (Supplementary Materials). The protons for aromatic rings resonated in the range 6.8-7.73 ppm for chlorophenyl and 6.86-7.46 for a naphthyl ring. The outside $\mathrm{H}$ atom of th chormene ring showed a simulated chemical shift at s $5.32 \mathrm{ppm}$ value. The $\mathrm{H}$-atoms for the $\mathrm{CH}_{3}$ group at $\mathrm{C}_{17}$ resonated theoretically at 3.84, 3.47, and $3.55 \mathrm{ppm}$. As expected, ${ }^{13} \mathrm{C}$ NMR chemical shifts of the entire phenyl carbon atoms were greater than $100 \mathrm{ppm}$. The predicted shifts were in the range of 110.78-141.54 for naphthalen and 122.12-137.45 for chlorophenyl rings. The predicted chemical shift for theOCH $\mathrm{H}_{3}$ was $51.84 \mathrm{ppm}$. The cyno group simulated a chemical shift at 104.25 ppm due to the adjecent nitrogen atom. The $C_{1} \& C_{2}$ in the chormen ring neighboring cyano and ClPhe groups predicated a chemical shift at 43.21 and $62.68 \mathrm{ppm}$. 
A

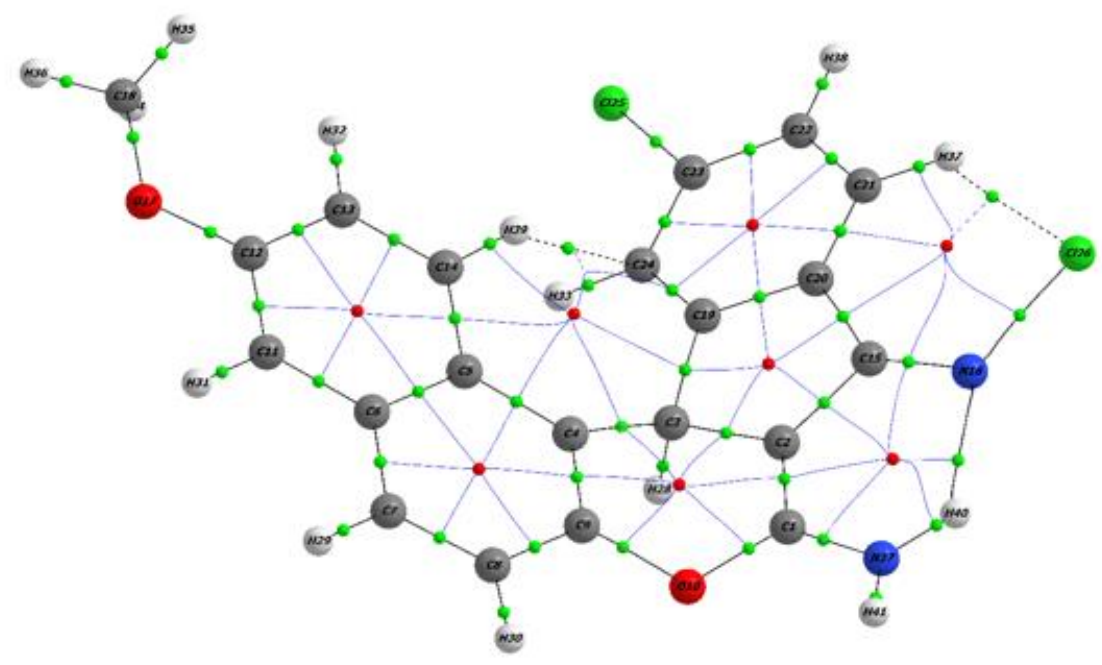

C
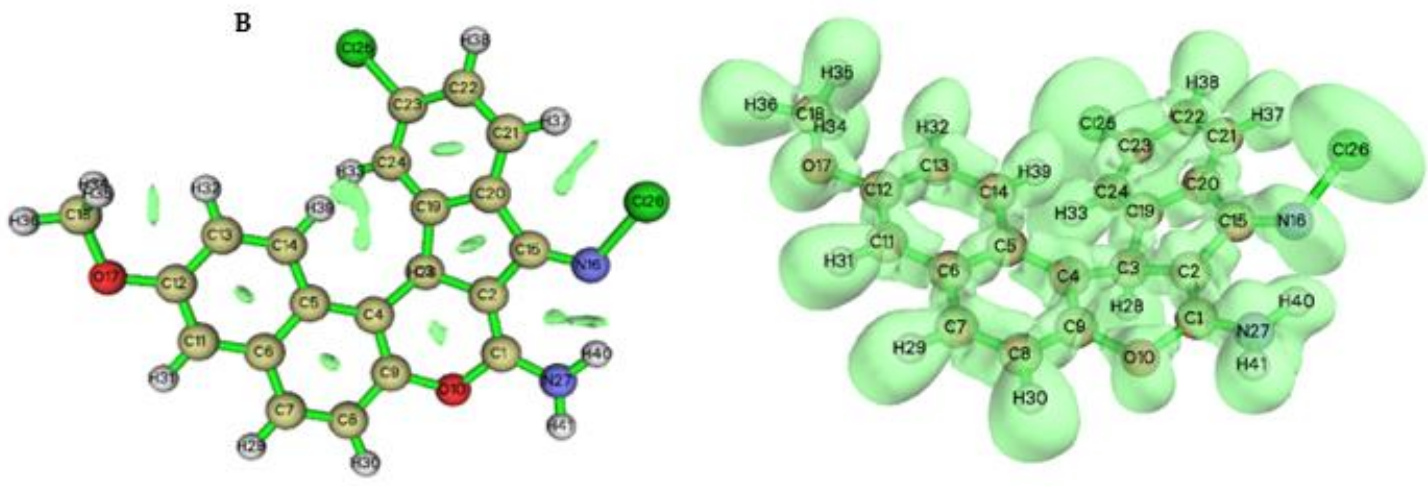

Figure 6. (A) bond paths and Bond Critical Points (BCP) in the studied system. Dashed bonds show weak intramolecular interactions of the $\mathrm{C}-\mathrm{H} \cdots \mathrm{O}$ type. (B) NCI isosurface and plot of the reduced density gradient (RDG) versus $\operatorname{sign}\left(\lambda \_2\right) \times \rho(\mathrm{r})$ of monomer, (C) ELF with a valence basin population.

\subsubsection{ADMET and Bioactivity Profile in Silico}

Oral-bioavailability plays a key role in drug design and discovery therapeutic activity of the molecule through the determination of Absorption, Distribution, Metabolism, Excretion, and Toxicity (ADMET) for the effective pharmacophoric sites in enhancing the antimicrobial or other biological activity [62]. The ADMET was measured for compound 4, camptothecin, and etoposide as standard drugs based on the POM analysis. The POM is a new and dynamic bioinformatics-platform [63] used to predict the pharmacophore sites with antitumor/antimicrobial efficiency. The POM analysis postulated that the compounds which have different charges $\left(\delta^{-}-\delta^{+}\right)$between two-heteroatoms in the same dipolar pharmacophoric site might inhibit tumor or bacterial growth over fungal strains [63-65]. For antifungal efficiency, the molecules should possess the same type of charge $\left(\delta^{-}-\delta^{-}\right)$in a pharmacophore site $[54,55]$.

The tautomer A for the tested compound 4 has an ideal antitumor pharmacophore site $\left(\mathrm{NH}^{\delta-}-\mathrm{CN}^{\delta+}\right)$. The microspecies-distribution (\%) for compound 4 in Figure 7 represents the neutral A, protonated B, and protonated C forms as illustrated in Scheme 2. Those forms are responsible for the regeneration of antitumor pharmacophore sites with higher $\mathrm{IC}_{50}$ than lower reference drugs against all tested cells. 


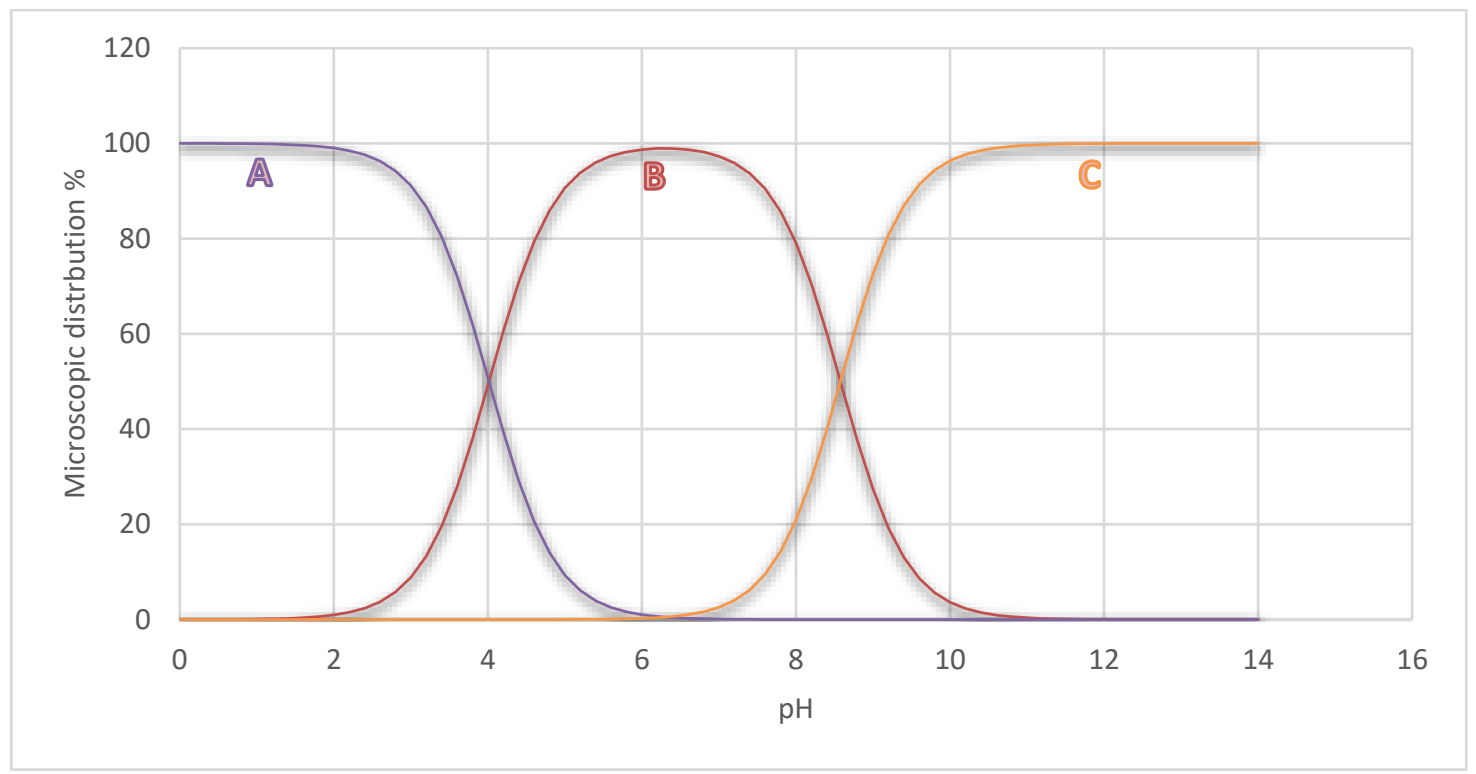

Figure 7. (A) The proposed potential antitumor pharmacophore sites according to POM analysis theory. (B,C) Microspecies distribution (\%) of neutral, protonated, and deprotonated forms of compound 4 as represented in Scheme 2, leading to regeneration of antitumor/antibacterial pharmacophore sites.

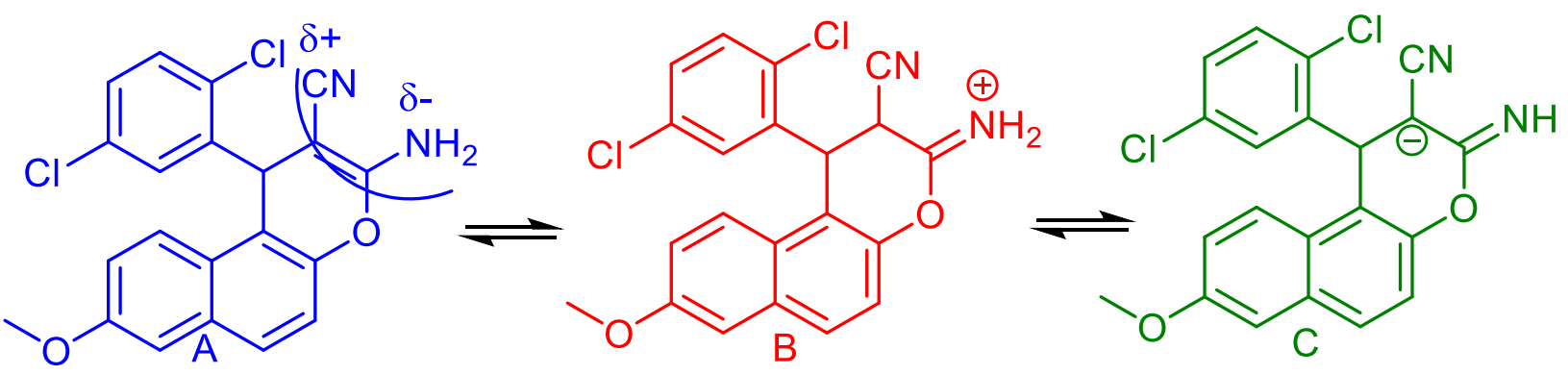

Scheme 2. Microspecies distribution (\%) of neutral (A), protonated (B), and deprotonated (C) forms for compound 4.

\subsection{Pharmacokinetic-Descriptors (Table S2, Figure S5; Supplementary Materials)}

The ADMET predicted profile data of compound 4 shown in (Table S3; Supplementary Materials) and reference drugs have fulfilled Lipinski rules [66]. Lipophilicity character $(\log P)<5.0$ for this compound showed a good permeability and absorption across the cell membrane [60]. TPSA is another important criterion in drug-likeness that systematized the membrane-permeability by referring to the polar atoms of the biomolecule. TPSA for compound 4 is lower than $140 \AA^{2}$, while reference drugs showed higher than ideal TPSA values [61]. That indicates that the tested compound is not passively absorbed with good absorption properties. Also, the drug likeness values were in the required limits. The hydrophilic-hydrophobic equilibrium state is important for the molecule solubility in aqueous media (blood, cytoplasm, etc.) and its distribution in membranes. Compared to the optimum value of $\operatorname{clog} P \approx 3$ [62], compounds 4 exhibited nearly optimum values $(\operatorname{cog} P=3.37)$ compared to etoposide and camptothecin with $\operatorname{cog} P=1.339$ and 2.08, respectively, as seen in Table S3.

\section{Bioactivity and Toxicity Risk Prediction}

The bioactivity score (absorption, distribution, excretion, and metabolism) is a critical measurement used to predict the potency of a biomolecule. The bioactivity scores were calculated by comparing structural known drug fragments with the tested compound [63]. The obtained data showed that the tested compound have promising bioactivity scores via 
models such as "GPCR" G protein-coupled receptors, "ICM" ion channel modulators, "KI" kinase inhibitors, " NRL" nuclear receptor ligand, "PI" protease inhibitor, and "EI" enzyme inhibitors (Table S3). We have investigated carcinogenic behaviors for the compound 4 by comparing the tested structures with 981 known various carcinogenic modules that were obtained from the "Carcinogenic Potency Database (CPDB)". The gained data from Table S3 showed:

i. No observed carcinogenic effect with ranged values for the synthesized compound $4(\sim 0.8-0.9 \mathrm{mg} / \mathrm{kg} \mathrm{bw} / \mathrm{d})$.

ii. The positive result against Caco-2 indicates a good permeability for the tested compound 4 (Caco-2 is a human colon epithelial cancer cell line, which is applied as a model for human intestinal absorption for medication).

iii. Compound 4 exhibits no acute oral toxicity observed with low acute lethal dose values for rat $(\mathrm{LD} 50=\sim 2.8-2.9 \mathrm{~mol} / \mathrm{kg})$.

iv. Compound 4 does not act as an inhibitor and substrate against $P$-glycoprotein, so we can safely retint these compounds without any effect [67-71].

v. A positivity acceptance with high permeability value through the BBB (blood brain barrier) indicates that compound 4 may be effective in treating tuberculosis meningitis [72].

vi. It has no mutagenic effect on the DNA of microorganisms when employing the Ames test (a wide examination of mutagenic effects for bioactive molecules against DNA of microorganisms [73].

vii. Compound 4 does not exhibit skin sensitivity (utilizing 254 compounds able to induce skin sensitization) and hepatotoxicity effects (using 531 compounds that have a liver-associated side effect in humans).

viii. This compound was not biodegradable when compared with 1604 compounds [74].

From the above features, we can conclude that the synthesized compound 4 may have a good oral bioavailability without any observed marked health effect.

\subsection{Molecular Docking}

DNA methyltransferases (DNMTs) catalyze the transfer of the $\mathrm{CH}_{3}$ group between S-adenosyl methionine (SAM) and cytosine in CpG dinucleotides. Three active forms of DNMTs are encoded as DNMT1, DNMT2, DNMT3A, DNMT3B, and DNMT3L [75]. DNMT1 is fundamental for normal mammalian growth, and it has been recommended as the major attractive target in anticancer therapies [76]. The genetic changes in breast cancer take place due to the high expression of DNMT1. The inhibition of DNA-methylation through DNMT1 inhibition is an important target for epigenetic-therapy [77]. Human DNMT1 includes 1616 amino acids. It contains two domains: catalytic and regulatory at C- and N-terminals, respectively [78,79]. The catalytic C-terminal domain includes 10 amino acids. The IX- motif includes DNA recognition. The I / X-motifs, and VI/ VIIImotifs belong to the cofactor, substrate, and binding pocket, respectively [80]. The DNMT1 crystal structure has been solved using a modeling-homology of this protein. The primarysequence of amino acids for DNMTs was retrieved from the NCBI (GenBank: AAD51619.1). The structural alignments by pBLAST [81] have been applied to get insights into the quality of the protein-folding. Its alignments allowed us to compare between several structures for the crystallized templates, suggested the similarity of the structures, and then assumed a satisfactory protein-folding form. The (5WVO_C) [82] and (5YDR_B) [83] models have been suggested for alignment by pBLAST as catalytic domain templates. Then, 3D structures of the alignment models were generated using HOMOLOGY module as implemented in Maestro [84] based on multiple-alignments, then minimization occurred in 200 illustration steps using an OPLS-2005 force field [85], followed by molecular-mechanics minimization. Finally, the model has been qualified using PROCHECK [86] for docking experiments. The pocket of the binding site was defined by CASTp server [87]. The $12 \AA \times 10 \AA \times 15 \AA$ grid box size with coordinates X:142 Y:16 Z:16 was configured in molecular docking simulations. To validate the grid box, we found a protein model with a similar fold as the query and 
which had a known crystal structure. The (PDB code: 4WXX) [88] was applied to redocking with the same reference ligand and tested compounds. The 400 poses were generated using the Schrödinger model [84]. The pose selected has the lowest docking score and the lowest RMSD and possesses a shorter distance than $(3 \AA)$ with vital amino acid residues of the active site, as shown in Figure 8. The obtained poses were energetically minimized with a default force field.

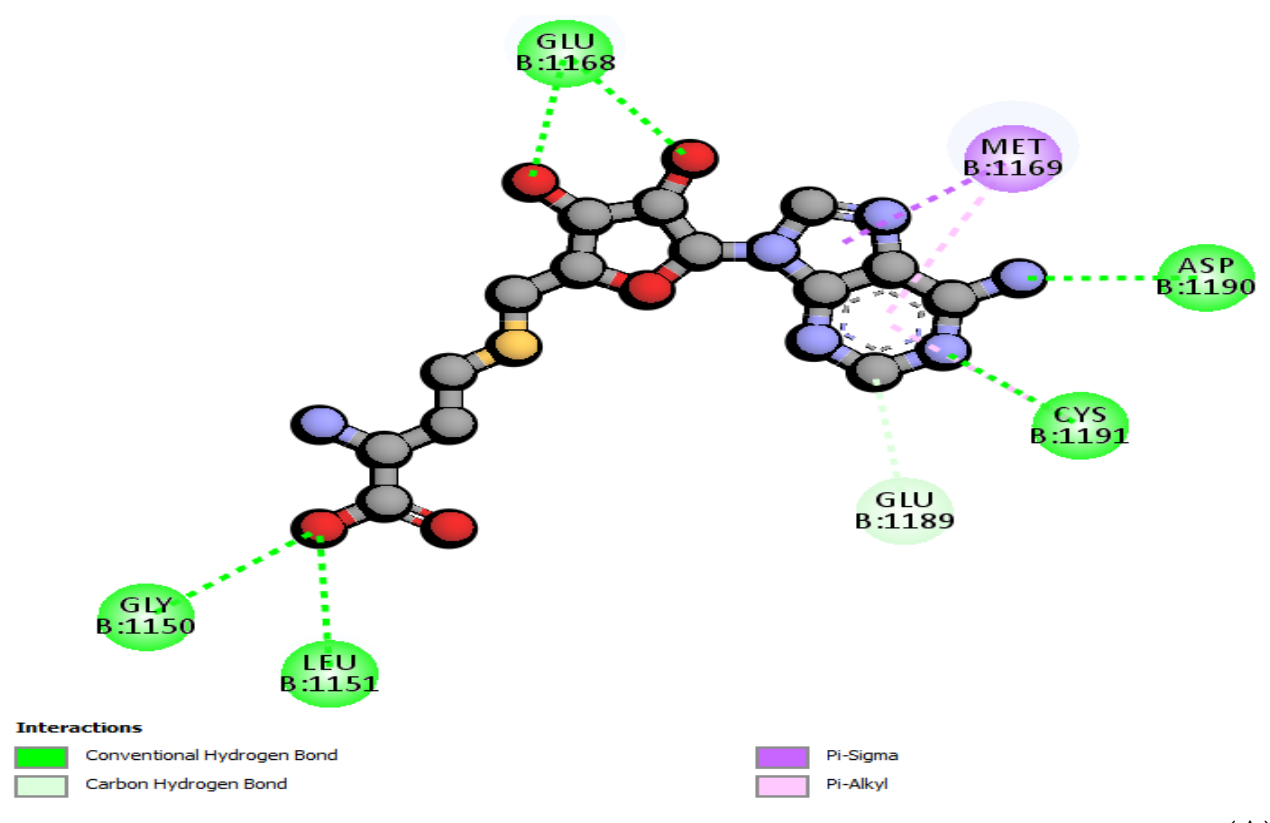

(A)

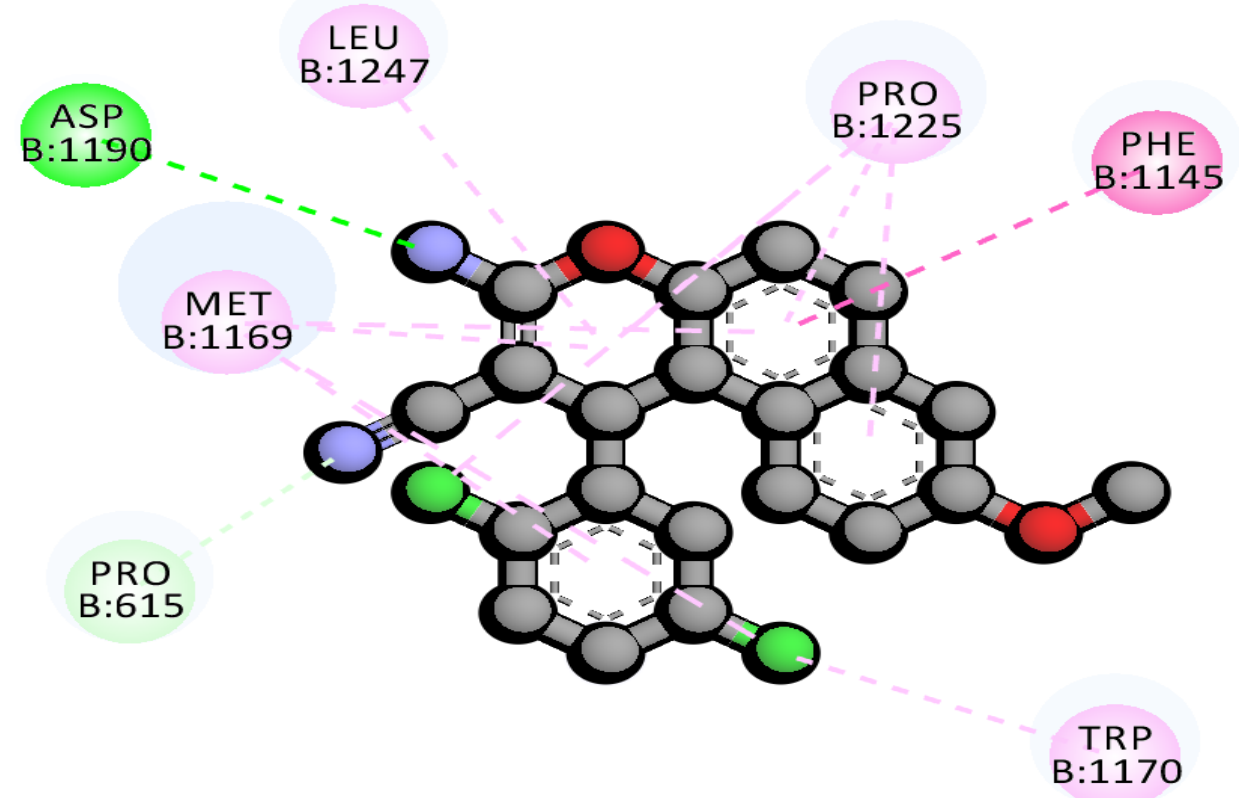

(B)

Figure 8. Cont. 


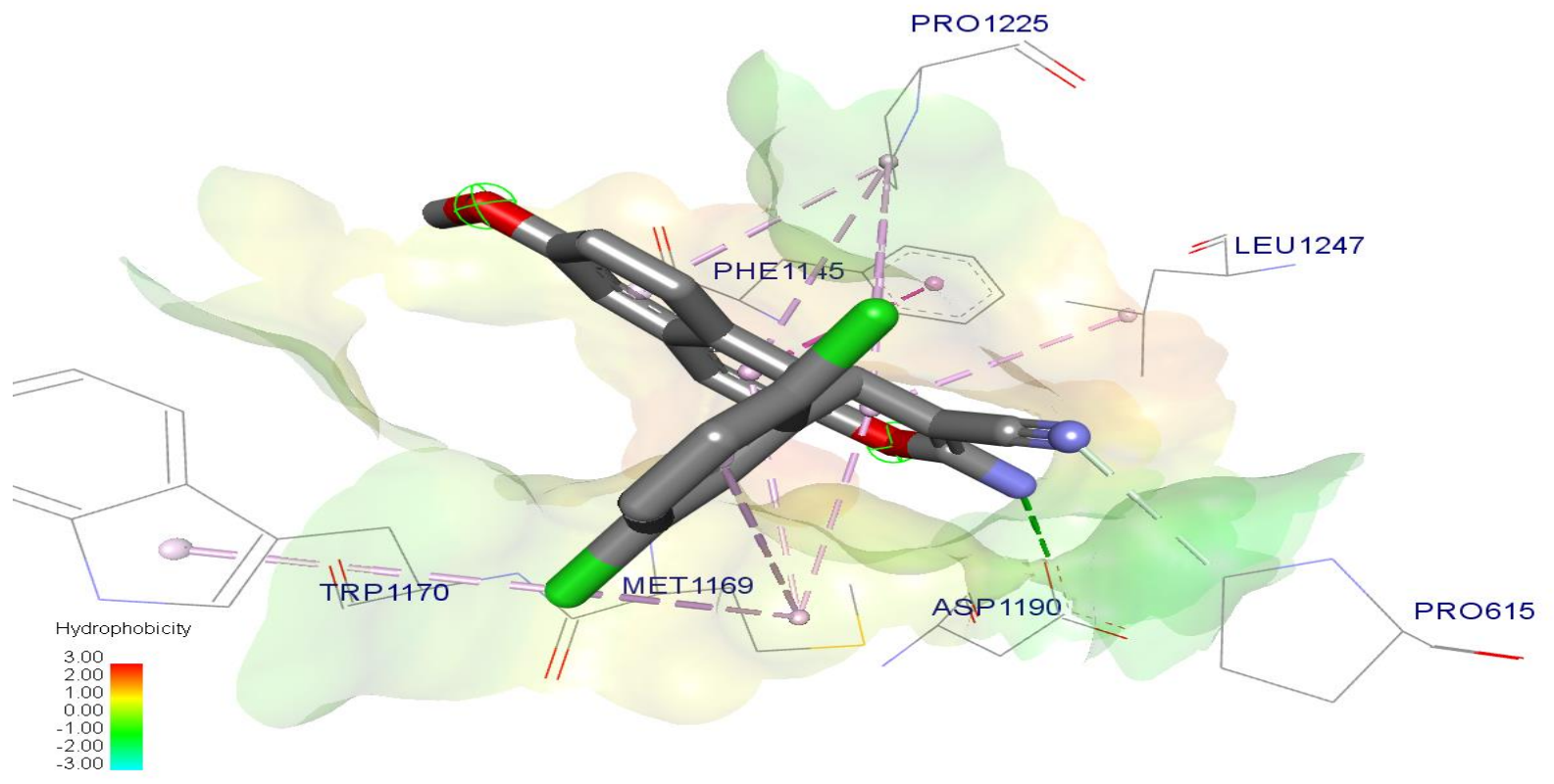

(C)

Figure 8. (A,B) 2D, and (C) 3D Binding patterns of compound 4 and S-ADENOSYL-L-HOMOCYSTEINE with an active site of DNMT1.

Compound 4 exhibited a binding score $(\Delta \mathrm{G}=-5.658 \mathrm{Kcal} / \mathrm{mol})$ that was nearly equal with the original inhibitor S-adenosyl-L-homocysteine $(\Delta \mathrm{G}=-6.412 \mathrm{Kcal} / \mathrm{mol})$, as shown in Table 6. Compound 4 exhibited a strong interaction with the same part of DNMT1 as S-adenosyl-L-homocysteine, as established with a tolerable overlay and is shown in Figure 8. The dichlorobenzene ring formed a H-bond interaction with ASP119 through Cl group which acts as an acceptor, while benzo[f]chromene moiety interacts with the vital amino acids backbone such as through PRO615, LEU1247, PHE1145, and MET1169 by a favorable hydrophobic contact with PHE1145 (see Figure 8). These data represent a circular interaction into the DNMT1 pocket that promises a suitable filling for this enzyme part. All these of interaction-kinds contributed to the promising docking affinity and $\Delta \mathrm{G}$ for compound 4. Compound 4 similarly as the reference drug appeared to block the same region formed by PRO615, LEU1247, PHE1145, MET1169, and ASP119 that fulfils the gateway of the protein pocket. This exposes the categories of DNMT1 inhibitors filtered as anticancer agents with promising $\mathrm{IC}_{50}$, as shown in Table 1.

Table 6. Docking energy scores $(\mathrm{kcal} / \mathrm{mol})$ for compound 4 and the reference ligand.

\begin{tabular}{ccc}
\hline Cpd. & 4 & Reference Inhibitor \\
\hline$\Delta \mathrm{G}$ & -5.458 & -6.508 \\
\hline RMSD & 0.802 & 1.637 \\
\hline Int. & -46.7218 & -30.9447 \\
\hline H.B. & -4.30374 & -4.55283 \\
\hline E ele & -87.417 & -100.927 \\
\hline Evdw & -104.168 & -72.201 \\
\hline L.E. & $-0.246 \pm 0.08^{*}$ & $-0.217 \pm 0.11^{*}$ \\
\hline
\end{tabular}

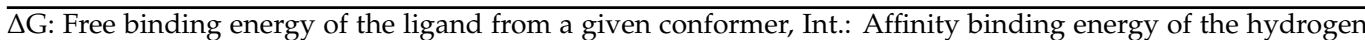
bond interaction with a receptor, H.B.: Hydrogen bonding energy between the protein and the ligand, E ele:

Electrostatic interaction with the receptor, Evdw: Van der Waals energies between the ligand and the receptor,

L.E.: Ligand efficiency. Excel was used to apply the Mean \pm SD test for the analyses of the ligand efficiency

* = statistically significant at the $5 \%$ level. 
Efficiency of Ligand based on Binding Energy

The variation between binding energy and heavy atoms is termed as a Efficiency ligand (LE) [89]. LE is considered to be a simple measurement to assess if the ligand is effective for an ideal fit against a targeted protein. The compound with a strong affinity to a small number of heavy atoms possesses high efficacy. The compound 4 showed similar values to S-adenosyl-L-homocysteine against DNMT1, as shown in Table 6.

\section{Materials and Methods}

\subsection{General Information}

All chemicals were purchased from Sigma-Aldrich Chemical Co. (St. Louis, MO, USA). The melting point was measured with a Stuart Scientific Co. Ltd apparatus and is uncorrected. The IR spectrum was recorded on a $\mathrm{KBr}$ disc on a Jasco FT/IR 460 plus spectrophotometer. The ${ }^{1} \mathrm{H}$ NMR $(500 \mathrm{MHz})$ and ${ }^{13} \mathrm{C}$ NMR $(125 \mathrm{MHz})$ spectra were measured on BRUKER AV $500 \mathrm{MHz}$ spectrometer in DMSO- $d_{6}$ as a solvent, using tetramethylsilane (TMS) as an internal standard, and chemical shifts were expressed as $\delta$ (ppm). The microwave apparatus used is Milestone Sr1, Microsynth. The mass spectrum was determined on a Shimadzu GC/MS-QP5050A spectrometer. Elemental analysis was carried out at the Regional Centre for Mycology and Biotechnology (RCMP), Al-Azhar University, Cairo, Egypt, and the results were within $\pm 0.25 \%$. Reaction courses and product mixtures were routinely monitored by thin layer chromatography (TLC) on silica gel precoated $\mathrm{F}_{254}$ Merck plates.

\subsection{Synthesis of}

3-Amino-1-(2,5-dichlorophenyl)-8-methoxy-1H-benzo[f]chromene-2-carbonitrile (4)

A reaction mixture of 6-methoxynaphthalen-2-ol (1) $(0.01 \mathrm{~mol}), 2,5$-dichlorobenzaldehyde (2) $(0.01 \mathrm{~mol})$, malononitrile (3) $(0.01 \mathrm{~mol})$, and piperidine $(0.5 \mathrm{~mL})$ in ethanol $(25 \mathrm{~mL})$ was heated under microwave irradiation conditions for $2 \mathrm{~min}$ at $140{ }^{\circ} \mathrm{C}$. After completion of the reaction, the reaction mixture was cooled to room temperature and the precipitated solid was filtered off, washed with methanol, and was recrystallized from ethanol to give compound 4 as colorless crystals; yield 82\%; m.p. $270-271^{\circ} \mathrm{C}$; $\mathrm{IR}(\mathrm{KBr}) v\left(\mathrm{~cm}^{-1}\right)$ : 3450, 3337, $3213\left(\mathrm{NH}_{2}\right)$, $2193(\mathrm{CN}){ }^{1}{ }^{1} \mathrm{H}$ NMR $\delta: 7.88-6.96$ (m, 8H, aromatic), 7.07 (bs, $\left.2 \mathrm{H}, \mathrm{NH}_{2}\right), 5.74(\mathrm{~s}, 1 \mathrm{H}, \mathrm{H}-1), 3.83(\mathrm{~s}$, $\left.3 \mathrm{H}, \mathrm{OCH}_{3}\right) ;{ }^{13} \mathrm{C}$ NMR $\delta: 160.08$ (C-3), 156.53 (C-8), 145.23 (C-4a), 131.98 (C-6a), 128.79 (C-10a), 128.64 (C-6), 123.95 (C-10), 119.77 (C-10b), 119.50 (C-9), 117.09 (C-7), 114.44 (CN), 107.65 (C-5), 55.59 (C-2), $55.21\left(\mathrm{CH}_{3}\right), 36.23$ (C-1), 145.63, 132.16, 129.15, 129.01, 128.93, 124.92 (aromatic); MS m/z (\%): $400\left(\mathrm{M}^{+}+4,45.79\right), 398\left(\mathrm{M}^{+}+2,15.27\right), 396\left(\mathrm{M}^{+}, 53.43\right)$ with a base peak at 180 (100); Anal. Calcd for $\mathrm{C}_{21} \mathrm{H}_{14} \mathrm{Cl}_{2} \mathrm{~N}_{2} \mathrm{O}_{2}$ (397.24): $\mathrm{C}, 63.49 ; \mathrm{H}, 3.55 ; \mathrm{N}, 7.05$. Found: $\mathrm{C}, 63.45 ; \mathrm{H}$, $3.51 ; \mathrm{N}, 7.01 \%$.

\subsection{Cytotoxic Activity}

\subsubsection{Cell Culture}

The cancer cell lines, the triple negative breast cancer (TNBC) MDA-MB-231, the non-small cell lung cancer (NSCLC) A549, and the pancreatic adenocarcinoma MIA PaCa-2 were obtained from the American Type Culture Collection (ATCC, Rockville, MD, USA) and cultured as recommended by the suppliers.

\subsubsection{Cytotoxicity Evaluation Using Cell Viability Assay}

The cytotoxic activity was appraised using sodium 3'-[1-(phenylaminocarbonyl)-3,4tetrazolium]-bis (4-methoxy-6-nitro) benzene sulfonic acid hydrate (XTT), as described in the literature $[35,36]$.

\subsection{X-ray Crystallography Analysis}

A suitable single crystal for the compound 4 was obtained by a slow evaporation technique for the ethanolic solution at room temperature. The Bruker APEX-II D8 Venture diffractometer was employed for data collection, and was equipped with graphite 
monochromatic Mo K $\alpha$ radiation, $\lambda=0.71073 \AA$ at 293 (2) K. Data reduction and cell refinement were carried out by Bruker SAINT. SHELXT was used to develop the structure [90,91]. CCDC 2054709 containing all crystallographic data of the compound 4 can be obtained free of charge from the Cambridge Crystallographic Data Centre via www.ccdc.cam.ac.uk/data_request/cif (accessed on 18 February 2021). The full-matrix least-squares techniques with anisotropic thermal data for non-hydrogen atoms on $F^{2}$ were employed for the final refinement of the structure.

\subsection{Computational Model}

All the quantum chemical computations were performed, using the DFT theory in Gaussian 09W [92] program package with the Becke3-Lee-Yang-parr (B3LYP) level using $6-311++G(d, p)$ basis. The single point calculations with $\mathrm{wfn}$ were used to calculate the following types of topological analysis for the molecular density: (i) the quantum theory of atoms in molecules (QTAIM); (ii) the non-covalent interactions index (NCI); (iii) an ELF (electron localization function). QTAIM, NCI, and ELF calculations were obtained from Multiwfn and the NCI plot program.

\subsection{Protein Preparation}

A 3D Crystal-structure for DNMT1 models was generated by a protein-preparation tool as implemented in Schrödinger-Suite-Maestro 20. Charges with bond orders were given and then $\mathrm{H}$-atoms were added, respectively. The $\mathrm{H}_{2} \mathrm{O}$ molecules were omitted. OPLS_2005 force field was applied for minimization with RMSD to $0.30 \AA$. Potential binding pockets were identified using a CASTp server [80], which applies the modern algorithmic and geometrical analysis for computational chemistry through the analyticalvalidation pockets and cavities.

\subsection{Molecular Docking}

The Molecular docking was performed by Glide-tools [93]. A grid was generated for protein using the default factors, and then charged by assignment with a force field OPLS [94]. A cubic-box was applied on the centroid-binding pocket to generate the receptor. The size of the box was assigned to $12 \AA \times 12 \AA \times 12 \AA$ for docking. Then, other molecular docking procedures were applied according to an original precision (SP) scoring function of the glide scoring function generated for measuring the binding affinity and the charges were assigned with a force field OPLS [94]. The structure with the lowest RMSD score was used to generate different poses of ligands.

\subsection{ADMET Predictions}

We used the ADMET profile in an attempt to identify of ADMET profile in silico (absorption, distribution, metabolism, excretion, and toxicity). The MOE and admetSAR tools were used for the prediction of pharmacokinetic parameters. The potential bioactivity was calculated, as well as the activity scores for distribution, excretion, and absorption parameters. The calculated drug-likeness scores of the tested compound were compared with each compound's specific activity and reference drugs.

\section{Conclusions}

In conclusion, 3-amino-1-(2,5-dichlorophenyl)-8-methoxy-1H-benzo[f]-chromene-2carbonitrile (4) was synthesized and characterized by ${ }^{1} \mathrm{H}$ NMR, ${ }^{13} \mathrm{C}$ NMR, elemental analysis, and X-ray single diffraction. The X-ray structure of the titled compound shows that bond lengths and angles were in normal ranges, while the dichlorophenyl moiety makes a plane which is perpendicular to the plane of $1 H$-benzo[f $]$ chromene moiety, with a dihedral angle equal to $89.33^{\circ}$. The antitumor activity was evaluated against the human cancer cell lines MDA-MB-231, A549, and MIA PaCa-2 in comparison to the positive controls etoposide and camptothecin, the obtained results revealed promising cytotoxic activities against the three cancer cell lines. The experimental data were co-related with DFT 
theoretical calculations using B3LYP/6-311++G(d,p) basis set. Furthermore, DFT has been used to gain a clear view of global with local molecular reactivity, and HOMO, LUMO and MEP were plotted to examine intermolecular interaction through the charge transfer within the molecule. Also, the molecular QTAIM and NCI to non-covalent interactions supported the importance of the $\mathrm{C}-\mathrm{H} \cdots \mathrm{O}$ interactions in the molecular self-packing of co-crystal. The ADMET profile in silico showed that its compound has a good oral bioavailability and high ability BBB transport, with no marked carcinogenic and health effects observed for the rodent toxicity profile. Molecular docking demonstrated high interaction-affinity with high stabilty in DNMT1. The theoretical and experimental investigations suggested that the compound has a promising anticancer activity with good oral bioavailability without any observed carcinogenesis effect.

Supplementary Materials: The following are available online at https:/ /www.mdpi.com/2073-435 2/11/2/184/s1, Figure S1: ${ }^{1} \mathrm{H}$ NMR of compound 4 in DMSO- $d_{6}$; Figure S2: ${ }^{1} \mathrm{H}$ NMR 8-6 ppm of compound 4 in DMSO- $d_{6}$ and Figure S3: ${ }^{13} \mathrm{C}$ NMR of compound 4 in DMSO- $d_{6}$; Figure S4: The full and decomposed fingerprint plots of the intermolecular contacts observed in the crystal structure of the compound 4; Figure S5: Calculated optimization structure of compound 4 using DFT with a B3LYP / 6-311++G(d,p); Figure S6: density gradient (RDG) versus sign $\left(\lambda \_2\right) \times \rho(r)$ of BZims monomer. Table S1; Summary of various contacts and their contributions to the Hirshfeld Surface; Table S2: Optimization geometry parameters for compound 4; Table S3: ADMET predicted profile; Table S4: Calculated local reactivity (in $\mathrm{eV}$ ) for the interacting atoms of compound 4; Table S5: Calculated NMR for 4 at B3LYP $/ 6-311+G(d, p)$.

Author Contributions: H.M.M., A.M.E.-A., A.E.-G.E.A., and A.A.A. designed the proposed methods and analyzed the spectral data; A.M.E.-A. performed the experiments and implemented the biological study; A.A.E. performed DFT theoretical calculations; M.E.G. performed biological experiments. M.E.G. and T.S. analyzed the biological data, and reviewed and edited the draft. H.A.G. carried out and wrote the X-ray processes. All authors have read and agreed to the published version of the manuscript.

Funding: Funding was obtained via the Vice Deanship of Scientific Research Chairs.

Acknowledgments: The authors are grateful to the Deanship of Scientific Research, King Saud University for funding through the Vice Deanship of Scientific Research Chairs.

Conflicts of Interest: The authors declare no conflict of interest.

\section{References}

1. Wang, Y.; Alenazy, R.; Gu, X.; Polyak, S.W.; Zhang, P.; Sykes, M.J.; Zhang, N.; Venter, H.; Ma, S. Design and structural optimization of novel $2 \mathrm{H}$-benzo[ $h]$ chromene derivatives that target AcrB and reverse bacterial multidrug resistance. Eur. J. Med. Chem. 2020, 113049. [CrossRef]

2. Radwan, H.A.M.; El-Mawgoud, H.K.A.; El-Mariah, F.; El-Agrody, A.M.; Amr, A.E.; Al-Omar, M.A.; Ghabbour, H.A. Single-Crystal Structure and Antimicrobial Activity of Ethyl 3-Amino-1-(4-chlorophenyl)-9-hydroxy-1H-benzo[f] chromene-2- carboxylate Combined with Ethyl $\alpha$-Cyano-4-chlorocinnamate. Russ. J. Gen. Chem. 2020, 90, 299-304. [CrossRef]

3. Fouda, A.M.; Hassan, A.H.; Eliwa, E.M.; Ahmed, H.E.A.; Al-Dies, A.A.M.; Omar, A.M.; Nassar, H.S.; Halawa, A.H.; Aljuhani, N.; El-Agrody, A.M. Targeted potent antimicrobial benzochromene-based analogues: Synthesis, computational studies, and inhibitory effect against $14 \alpha$-Demethylase and DNA Gyrase. Bioorg. Chem. 2020, 105, 104387. [CrossRef]

4. Abd El-Mawgoud, H.K.; Radwan, H.A.M.; El-Mariah, F.; El-Agrody, A.M. Synthesis, Characterization, Biological Activity of Novel $1 H$-benzo[ $f]$ chromene and $12 H$-benzo[ $f]$ chromeno[2,3-d]pyrimidine Derivatives. Lett. Drug Des. Discov. 2018, 15, 857-865. [CrossRef]

5. Abdella, A.M.; Moatasim, Y.; Ali, M.A.; Elwahy, A.H.M.; Abdelhamid, I.A. Synthesis and Anti-influenza Virus Activity of Novel bis(4H-chromene-3-carbonitrile) Derivatives. J. Heterocycl. Chem. 2017, 54, 1854-1862. [CrossRef]

6. Jayaprakash Rao, Y.; Yadaiah Goud, E.; Hemasri, Y.; Jain, N.; Gabriella, S. Synthesis and antiproliferative activity of 6,7aryl/hetaryl coumarins. Russ. J. Gen. Chem. 2016, 86, 184-189. [CrossRef]

7. Parthiban, A.; Kumaravel, M.; Muthukumaran, J.; Rukkumani, R.; Krishna, R.; Rao, H.S.P. Synthesis, in vitro and in silico anti-proliferative activity of 4-aryl-4H-chromene derivatives. Med. Chem. Res. 2016, 25, 1308-1315. [CrossRef]

8. Ahagh, M.H.; Dehghan, G.; Mehdipour, M.; Teimuri-Mofrad, R.; Payami, E.; Sheibani, N.; Ghaffari, M.; Asadid, M. Synthesis, characterization, anti-proliferative properties and DNA binding of benzochromene derivatives: Increased Bax/Bcl-2 ratio and caspasedependent apoptosis in colorectal cancer cell. Bioorg. Chem. 2019, 93, 103329. [CrossRef] 
9. Fu, Z.-Y.; Jin, Q.-H.; Qu, Y.-L.; Guan, L.-P. Chalcone derivatives bearing chromen or benzo[f]chromen moieties: Design, synthesis, and evaluations of anti-inflammatory, analgesic, selective COX-2 inhibitory activities. Bioorg. Med. Chem. Lett. 2019, 29, 1909-1912. [CrossRef]

10. Dehkordi, M.F.; Dehghan, G.; Mahdavi, M.; Feizi, M.A.H. Multispectral studies of DNA binding, antioxidant and cytotoxic activities of a new pyranochromene derivative. Spectrochim. Acta Part A 2015, 145, 353-359. [CrossRef]

11. Schmitt, F.; Gold, M.; Rothemund, M.; Andronache, I.; Biersack, B.; Schobert, R.; Mueller, T. New naphthopyran analogues of LY290181 as potential tumor vascular-disrupting agents. Eur. J. Med. Chem. 2019. [CrossRef] [PubMed]

12. Alblewi, F.F.; Okasha, R.M.; Eskandrani, A.A.; Afifi, T.H.; Mohamed, H.M.; Halawa, A.H.; Fouda, A.M.; Al-Dies, A.A.M.; Mora, A.; El-Agrody, A.M. Design and Synthesis of Novel Heterocyclic-Based $4 H$-benzo $[h]$ chromene Moieties: Targeting antitumor caspase $3 / 7$ activities and cell cycle analysis. Molecules 2019, 24, 1060. [CrossRef] [PubMed]

13. Haiba, M.E.; Al-Abdullah, E.S.; Ghabbour, H.A.; Riyadh, S.M.; Abdel-Kader, R.M. Inhibitory activity of benzo[ $h]$ quinoline and benzo[ $h$ ]chromene in human glioblastoma cells. Trop. J. Pharm. Res. 2016, 15, 2337-2343. [CrossRef]

14. Haiba, M.E.; Al-Abdullah, E.S.; Ahmed, N.S.; Ghabbour, H.A.; Awad, H.M. Efficient and easy synthesis of new Benzo[ $h]$ chromene and Benzo[ $h]$ quinoline derivatives as a new class of cytotoxic agents. J. Mol. Struct. 2019, 1195, 702-711. [CrossRef]

15. Kheirollahi, A.; Pordeli, M.; Safavi, M.; Mashkouri, S.; Naimi-Jamal, M.R.; Ardestani, S.K. Cytotoxic and apoptotic effects of synthetic benzochromene derivatives on human cancer cell lines. Naunyn-Schmiedeberg's Arch. Pharmacol. 2014, 387, 1199-1208. [CrossRef]

16. El-Agrody, A.M.; Abd El-Mawgoud, H.K.; Fouda, A.M.; Khattab, E.S.A.E.H. Synthesis, in-vitro cytotoxicity of 4Hbenzo[ $h]$ chromene derivatives and structure-activity relationships of 4-aryl group and 3-, 7-positions. Chem. Pap. 2016, 70, 1279-1292. [CrossRef]

17. El-Agrody, A.M.; Fouda, A.M.; Khattab, E.S.A.E.H. Synthesis, antitumor activity of 2-amino-4H-benzo[ $h]$ chromene derivatives, and structure-activity relationships of the 3- and 4-positions. Med. Chem. Res. 2013, 22, 6105-6120. [CrossRef]

18. El-Agrody, A.M.; Fouda, A.M.; Khattab, E.S.A.E.H. Halogenated 2-amino-4H-benzo[ $h]$ chromene derivatives as antitumor agents and the relationship between lipophilicity and antitumor activity. Med. Chem. Res. 2017, 26, 691-700. [CrossRef]

19. Okasha, R.M.; Alblewi, F.F.; Afifi, T.H.; Naqvi, A.; Fouda, A.M.; Al-Dies, A.A.M.; El-Agrody, A.M.; Belmont, P.; Bunce, R.A. Design of new Benzo[ $h]$ chromene derivatives: Antitumor activities and structure-activity relationships of the 2,3-Positions and fused rings at the 2,3-positions. Molecules 2017, 22, 479. [CrossRef]

20. Halawa, A.H.; Fouda, A.M.; Al-Dies, A.-A.M.; El-Agrody, A.M. Synthesis, Biological Evaluation and Molecular Docking Studies of $4 H$-benzo[ $h]$ chromenes, $7 H$-benzo[ $h]$ chromeno[2,3-d]pyrimidines as Antitumor Agents. Lett. Drug Des. Discov. 2015, 13, 77-88. [CrossRef]

21. El-Agrody, A.M.; Fouda, A.M.; Al-Dies, A.A.M. Studies on the synthesis, in vitro antitumor activity of $4 H$-benzo[ $h]$ chromene, $7 H$-benzo[ $h]$ chromene[2,3- $d]$ pyrimidine derivatives and structure-Activity relationships of the 2-,3- and 2,3-positions. Med. Chem. Res. 2014, 23. [CrossRef]

22. Ahmed, H.E.A.; El-Nassag, M.A.A.; Hassan, A.H.; Okasha, R.M.; Ihmaid, S.; Fouda, A.M.; Afifi, T.H.; Aljuhani, A.; El-Agrody, A.M. Introducing novel potent anticancer agents of $1 H$-benzo[f]chromene scaffolds, targeting c-Src kinase enzyme with MDA-MB-231 cell line anti-invasion effect. J. Enzyme Inhib. Med. Chem. 2018, 33. [CrossRef] [PubMed]

23. Piazzi, L.; Cavalli, A.; Belluti, F.; Bisi, A.; Gobbi, S.; Rizzo, S.; Bartolini, M.; Andrisano, V.; Recanatini, M.; Rampa, A. Extensive SAR and computational studies of 3-\{4-[(benzylmethylamino)methyl] phenyl\}-6,7-dimethoxy-2H-2-chromenone (AP2238) derivatives. J. Med. Chem. 2007, 50. [CrossRef] [PubMed]

24. Gorle, S.; Maddila, S.; Maddila, S.; Naicker, K.; Singh, M.; Singh, P.; Jonnalagadda, S. Synthesis, Molecular Docking Study and in vitro Anticancer Activity of Tetrazole Linked Benzochromene Derivatives. Anticancer Agents Med. Chem. 2017, 17. [CrossRef]

25. Afifi, T.H.; Okasha, R.M.; Ahmed, H.E.A.; Ilaš, J.; Saleh, T.; Abd-El-aziz, A.S. Structure-activity relationships and molecular docking studies of chromene and chromene based azo chromophores: A novel series of potent antimicrobial and anticancer agents. EXCLI J. 2017, 16, 868. [CrossRef]

26. Fouda, A.M.; Assiri, M.A.; Mora, A.; Ali, T.E.; Afifi, T.H.; El-Agrody, A.M. Microwave synthesis of novel halogenated $\beta$ enaminonitriles linked 9-bromo- $1 H$-benzo[ $f$ chromene moieties: Induces cell cycle arrest and apoptosis in human cancer cells via dual inhibition of topoisomerase I and II. Bioorg. Chem. 2019, 93. [CrossRef]

27. Fouda, A.M.; Okasha, R.M.; Alblewi, F.F.; Mora, A.; Afifi, T.H.; El-Agrody, A.M. A proficient microwave synthesis with structure elucidation and the exploitation of the biological behavior of the newly halogenated 3-amino- $1 H$-benzo[f]chromene molecules, targeting dual inhibition of topoisomerase II and microtubules. Bioorg. Chem. 2020, 95. [CrossRef]

28. Okasha, R.M.; Amr, A.E.; El-Agrody, A.M.; Al-Omar, M.A.; Ghabbour, H.A. Crystal structure of 3-amino-8-methoxy-1-phenyl-1Hbenzo[f]chromene-2-carbonitrile, $\mathrm{C}_{21} \mathrm{H}_{16} \mathrm{~N}_{2} \mathrm{O}_{2}$. Z. Kristallogr. NCS 2017, 232. [CrossRef]

29. Mohamed, H.M.; Amr, A.E.; El-Agrody, A.M.; Al-Omar, M.A.; Ghabbour, H.A. Crystal structure of 3-amino-1-(4-bromophenyl)-9methoxy-1H-benzo[f]chromene-2-carbonitrile, $\mathrm{C}_{21} \mathrm{H}_{15} \mathrm{BrN}_{2} \mathrm{O}_{2}$. Z. Kristallogr. NCS 2017, 232. [CrossRef]

30. Fouda, A.M.; Amr, A.E.; El-Agrody, A.M.; Al-Omar, M.A.; Ghabbour, H.A. Crystal structure of 3-amino-8-methoxy-1-(4-methoxy phenyl)-1H-benzo[f]chromene-2-carbonitrile, $\mathrm{C}_{22} \mathrm{H}_{18} \mathrm{~N}_{2} \mathrm{O}_{3}$. Z. Kristallogr. NCS 2017, 232. [CrossRef]

31. Okasha, R.M.; Alblewi, F.F.; Assiri, M.A.; Amr, A.E.; Ghabbour, H.A.; Afifi, T.H.; El-Agrody, A.M. Crystal Structure and Spectral Studies of 3-Amino-9-Methoxy-1-(4-methoxyphenyl)-1H-Benzo[f]Chromene-2-Carbonitrile. J. Comput. Theor. Nanosci. 2018, 15. [CrossRef] 
32. Okasha, R.M.; El-Agrody, A.M.; Amr, A.E.; Al-Omar, M.A.; Ghabbour, H.A. Synthesis and X-ray Single Crystals Characterizations of 2-Amino-4-(2-chlorophenyl)-6-Chloro-4H-Benzo[h]Chromene-3-Carbonitrile. J. Comput. Theor. Nanosci. 2017, 14, 5286-5291. [CrossRef]

33. Amr, A.E.; Abd El-Mawgoud, H.K.; El-Agrody, A.M.; Al-Omar, A.E.; Alsultan, M.S. X-ray, Microwave Assisted Synthesis and Spectral Data of 3-Amino-1-(3,5-dibromo-2-methoxyphenyl)-8-methoxy-1H-benzo[f]-chromene-2-carbonitrile. J. Comput. Theor. Nanosci. 2017, 14, 3930-3935. [CrossRef]

34. Afifi, T.H.; El-Agrody, A.M.; Amr, A.E.; Al-Omar, A.E.; Ghabbour, H.A. X-ray Characterization and Antimicrobial Activity of Synthesized New 3-Amino-8-Bromo-1-(3,4-dimethoxyphenyl)-1H-Benzo[f]-Chromene-2-Carbonitrile. J. Comput. Theor. Nanosci. 2017, 14, 3924-3929. [CrossRef]

35. Paull, K.D.; Shoemaker, R.H.; Boyd, M.R.; Parsons, J.L.; Risbood, P.A.; Barbera, W.A.; Sharma, M.N.; Baker, D.C.; Hand, E.; Scudiero, D.A.; et al. The synthesis of XTT: A new tetrazolium reagent that is bioreducible to a water-soluble formazan. J. Heterocycl. Chem. 1988, 25, 911-914. [CrossRef]

36. Scudiere, D.A.; Shoemaker, R.H.; Paull, K.D.; Monks, A.; Tierney, S.; Nofziger, T.H.; Currens, M.J.; Seniff, D.; Boyd, M.R. Evaluation of a Soluble Tetrazolium/Formazan Assay for Cell Growth and Drug Sensitivity in Culture Using Human and Other Tumor Cell Lines. Cancer Res. 1988, 48, 4827-4833.

37. Allen, F.H.; Kennard, O.; Watson, D.G.; Brammer, L.; Orpen, A.G.; Taylor, R. Tables of bond lengths determined by x-ray and neutron diffraction. Part 1. Bond lengths in organic compounds. J. Chem. Soc. Perkin Trans. 2 1987, S1-S19. [CrossRef]

38. McKinnon, J.J.; Fabbiani, F.P.A.; Spackman, M.A. Comparison of polymorphic molecular crystal structures through hirshfeld surface analysis. Cryst. Growth Des. 2007, 7. [CrossRef]

39. Dalal, J.; Sinha, N.; Yadav, H.; Kumar, B. Structural, electrical, ferroelectric and mechanical properties with Hirshfeld surface analysis of novel NLO semiorganic sodium p-nitrophenolate dihydrate piezoelectric single crystal. RSC Adv. 2015, 5. [CrossRef]

40. Mackenzie, C.F.; Spackman, P.R.; Jayatilaka, D.; Spackman, M.A. CrystalExplorer model energies and energy frameworks: Extension to metal coordination compounds, organic salts, solvates and open-shell systems. IUCrJ 2017, 4. [CrossRef] [PubMed]

41. Fukui, K. Role of frontier orbitals in chemical reactions. Science 1982, 218, 747-754. [CrossRef]

42. Hofmann, P. Arvi Rauk:“Orbital Interaction Theory of Organic Chemistry” Wiley \& Sons: New York, NY, USA, 1994, ISBN 0-47159389-3. 307 Seiten, mit HMO-Programmdiskette, Preis: \$45.50. Ber. Bunsenges. Phys. Chem. 1995, 99, 997-999.

43. Wildman, S.A.; Crippen, G.M. Prediction of physicochemical parameters by atomic contributions. J. Chem. Inf. Comput. Sci. 1999, 39, 868-873. [CrossRef]

44. Ayers, P.W.; Parr, R.G. Variational principles for describing chemical reactions: The Fukui function and chemical hardness revisited. J. Am. Chem. Soc. 2000, 122, 2010-2018. [CrossRef]

45. Lamaka, S.V.; Zheludkevich, M.L.; Yasakau, K.A.; Serra, R.; Poznyak, S.K.; Ferreira, M.G.S. Nanoporous titania interlayer as reservoir of corrosion inhibitors for coatings with self-healing ability. Prog. Org. Coat. 2007, 58, 127-135. [CrossRef]

46. Komorowski, L.; Lipinski, J.; Szarek, P.; Ordon, P. Polarization justified Fukui functions: The theory and applications for molecules. J. Chem. Phys. 2011, 135, 14109. [CrossRef] [PubMed]

47. Mendoza-Huizar, L.H.; Rios-Reyes, C.H.; Álvarez-Romero, G.A.; Palomar-Pardavé, M.E.; Ramírez-Silva, M.T. Electrophilic and nucleophilic chemical reactivity of neutral and anionic forms of 4-cpa, 24d-cpa, 34-cpa and 245t-cpa through conceptual dft reactivity descriptors. J. Chil. Chem. Soc. 2017, 62, 3411-3416. [CrossRef]

48. Elhenawy, A.A.; Al-Harbi, L.M.; El-Gazzar, M.A.; Khowdiary, M.M.; Moustfa, A. Synthesis, molecular properties and comparative docking and QSAR of new 2-(7-hydroxy-2-oxo-2H-chromen-4-yl)acetic acid derivatives as possible anticancer agents. Spectrochim. Acta Part A Mol. Biomol. Spectrosc. 2019, 218, 248-262. [CrossRef]

49. Luque, F.J.; López, J.M.; Orozco, M. Perspective on Electrostatic interactions of a solute with a continuum. A direct utilization of $\mathrm{ab}$ initio molecular potentials for the prevision of solvent effects. In Theoretical Chemistry Accounts; Springer: Berlin, Germany, 2000; pp. 343-345.

50. Mendoza-Huizar, L.H.; Rios-Reyes, C.H. Chemical reactivity of atrazine employing the Fukui function. J. Mex. Chem. Soc. 2011, 55, 142-147.

51. Sureshkumar, B.; Mary, Y.S.; Panicker, C.Y.; Suma, S.; Armaković, S.; Armaković, S.J.; Van Alsenoy, C.; Narayana, B. Quinoline derivatives as possible lead compounds for anti-malarial drugs: Spectroscopic, DFT and MD study. Arab. J. Chem. 2017, 13, 632-648. [CrossRef]

52. War, J.A.; Jalaja, K.; Mary, Y.S.; Panicker, C.Y.; Armaković, S.; Armaković, S.J.; Srivastava, S.K.; Van Alsenoy, C. Spectroscopic characterization of 1-[3-(1H-imidazol-1-yl) propyl]-3-phenylthiourea and assessment of reactive and optoelectronic properties employing DFT calculations and molecular dynamics simulations. J. Mol. Struct. 2017, 1129, 72-85. [CrossRef]

53. Elhenawy, A.A.; Al-Harbi, L.M.; Moustafa, G.O.; El-Gazzar, M.A.; Abdel-Rahman, R.F.; Salim, A.E. Synthesis, comparative docking, and pharmacological activity of naproxen amino acid derivatives as possible anti-inflammatory and analgesic agents. Drug Des. Dev. Ther. 2019, 13. [CrossRef] [PubMed]

54. Ali, I.O.; Nassar, H.S.; El-Nasser, K.S.; Bougarech, A.; Abid, M.; Elhenawy, A.A. Synthesis and characterization of MnII and CoII complexes with poly (vinyl alcohol-nicotinic acid) for photocatalytic degradation of Indigo carmine dye. Inorg. Chem. Commun. 2021, 124, 108360. [CrossRef]

55. Theophilou, A.K. A novel density functional theory for atoms, molecules, and solids. J. Chem. Phys. 2018. [CrossRef] [PubMed] 
56. Bader, R.F.W. Atoms in Molecules: A Quantum Theory, International Series of Monographs on Chemistry 22. Oxford University Press. Oxford Henkelman G, Arnaldsson A, Jónsson H A fast robust algorithm Bader decomposition of charge density. Comput. Mater. Sci. 1990, 88, 899 .

57. Lane, J.R.; Contreras-García, J.; Piquemal, J.P.; Miller, B.J.; Kjaergaard, H.G. Are bond critical points really critical for hydrogen bonding? J. Chem. Theory Comput. 2013, 9, 3263-3266. [CrossRef]

58. Johnson, E.R.; Keinan, S.; Mori-Sánchez, P.; Contreras-García, J.; Cohen, A.J.; Yang, W. Revealing noncovalent interactions. J. Am. Chem. Soc. 2010, 132, 6498-6506. [CrossRef] [PubMed]

59. Contreras-García, J.; Yang, W.; Johnson, E.R. Analysis of hydrogen-bond interaction potentials from the electron density: Integration of noncovalent interaction regions. J. Phys. Chem. A 2011, 115, 12983-12990. [CrossRef]

60. Lu, T.; Chen, F. Multiwfn: A multifunctional wavefunction analyzer. J. Comput. Chem. 2012. [CrossRef]

61. Wolinski, K.; Hinton, J.F.; Pulay, P. Efficient Implementation of the Gauge-Independent Atomic Orbital Method for NMR Chemical Shift Calculations. J. Am. Chem. Soc. 1990, 397-409. [CrossRef]

62. Sheikh, J.; Hatzade, K.; Bader, A.; Shaheen, U.; Sander, T.; Ben Hadda, T. Computational evaluation and experimental verification of antibacterial and antioxidant activity of 7-hydroxy-3-pyrazolyl-4H-chromen-4-ones and their o-glucosides: Identification of pharmacophore sites. Med. Chem. Res. 2014, 23, 243-251. [CrossRef]

63. Ahsan, M.J.; Govindasamy, J.; Khalilullah, H.; Mohan, G.; Stables, J.P.; Pannecouque, C.; Clercq, E. De POMA analyses as new efficient bioinformatics' platform to predict and optimise bioactivity of synthesized 3a,4-dihydro-3H-indeno[1,2-c]pyrazole-2carboxamide/carbothioamide analogues. Bioorg. Med. Chem. Lett. 2012, 22, 7029-7035. [CrossRef] [PubMed]

64. Mabkhot, Y.N.; Arfan, M.; Zgou, H.; Genc, Z.K.; Genc, M.; Rauf, A.; Bawazeer, S.; Ben Hadda, T. How to improve antifungal bioactivity: POM and DFT study of some chiral amides derivatives of diacetyl-L-tartaric acid and amines. Res. Chem. Intermed. 2016, 42, 8055-8068. [CrossRef]

65. Rachedi, K.O.; Ouk, T.-S.; Bahadi, R.; Bouzina, A.; Djouad, S.-E.; Bechlem, K.; Zerrouki, R.; Ben Hadda, T.; Almalki, F.; Berredjem, M. Synthesis, DFT and POM analyses of cytotoxicity activity of $\alpha$-amidophosphonates derivatives: Identification of potential antiviral O,O-pharmacophore site. J. Mol. Struct. 2019, 1197, 196-203. [CrossRef]

66. Lipinski, C.A. Lead-and drug-like compounds: The rule-of-five revolution. Drug Discov. Today Technol. 2004, 1, 337-341. [CrossRef] [PubMed]

67. Sliwoski, G.; Kothiwale, S.; Meiler, J.; Lowe, E.W. Computational methods in drug discovery. Pharmacol. Rev. 2014, 66, 334-395. [CrossRef] [PubMed]

68. Zhao, Y.H.; Abraham, M.H.; Le, J.; Hersey, A.; Luscombe, C.N.; Beck, G.; Sherborne, B.; Cooper, I. Rate-limited steps of human oral absorption and QSAR studies. Pharm. Res. 2002, 19, 1446-1457. [CrossRef] [PubMed]

69. Zheng, M.; Liu, X.; Xu, Y.; Li, H.; Luo, C.; Jiang, H. Computational methods for drug design and discovery: Focus on China. Trends Pharmacol. Sci. 2013, 34, 549-559. [CrossRef]

70. Husain, A.; Ahmad, A.; Khan, S.A.; Asif, M.; Bhutani, R.; Al-Abbasi, F.A. Synthesis, molecular properties, toxicity and biological evaluation of some new substituted imidazolidine derivatives in search of potent anti-inflammatory agents. J Saudi Pharm. J. 2016, 24, 104-114. [CrossRef]

71. Amin, M.L. P-glycoprotein inhibition for optimal drug delivery. Drug Target Insights 2013, 7, 27-34. [CrossRef]

72. Schinkel, A.H. P-Glycoprotein, a gatekeeper in the blood-brain barrier. Adv. Drug Deliv. Rev. 1999, 36, 179-194. [CrossRef]

73. Mortelmans, K.; Zeiger, E. The Ames Salmonella/microsome mutagenicity assay. J Mutat. Res. Mol. Mech. Mutagen. 2000, 455, 29-60. [CrossRef]

74. Shen, J.; Cheng, F.; Xu, Y.; Li, W.; Tang, Y. Estimation of ADME properties with substructure pattern recognition. J. Chem. Inf. Model. 2010, 50, 1034-1041. [CrossRef] [PubMed]

75. Lyko, F. The DNA methyltransferase family: A versatile toolkit for epigenetic regulation. Nat. Rev. Genet. 2018, 19, 81-92. [CrossRef]

76. Dueñas-González, A.; Jesús Naveja, J.; Medina-Franco, J.L. Introduction of Epigenetic Targets in Drug Discovery and Current Status of Epi-Drugs and Epi-Probes. In Epi-Informatics: Discovery and Development of Small Molecule Epigenetic Drugs and Probes; Elsevier: Amsterdam, The Netherlands, 2016; ISBN 9780128028094.

77. Fahy, J.; Jeltsch, A.; Arimondo, P.B. DNA methyltransferase inhibitors in cancer: A chemical and therapeutic patent overview and selected clinical studies. Expert Opin. Ther. Pat. 2012, 22, 1427-1442. [CrossRef] [PubMed]

78. Jurkowska, R.Z.; Jurkowski, T.P.; Jeltsch, A. Structure and Function of Mammalian DNA Methyltransferases. ChemBioChem 2011, 12, 206-222. [CrossRef] [PubMed]

79. Edwards, J.R.; Yarychkivska, O.; Boulard, M.; Bestor, T.H. DNA methylation and DNA methyltransferases. Epigenetics Chromatin 2017, 10, 23. [CrossRef]

80. Lan, J.; Hua, S.; He, X.; Zhang, Y. DNA methyltransferases and methyl-binding proteins of mammals. Acta Biochim. Biophys. Sin. 2010, 42, 243-252. [CrossRef] [PubMed]

81. Madden, T. The BLAST Sequence Analysis Tool; National Center for Biotechnology Information (US): Bethesda, MA, USA, 2013.

82. Ishiyama, S.; Nishiyama, A.; Saeki, Y.; Moritsugu, K.; Morimoto, D.; Yamaguchi, L.; Arai, N.; Matsumura, R.; Kawakami, T.; Mishima, Y.; et al. Structure of the Dnmt1 Reader Module Complexed with a Unique Two-Mono-Ubiquitin Mark on Histone H3 Reveals the Basis for DNA Methylation Maintenance. Mol. Cell 2017, 68, 350-360.e7. [CrossRef] 
83. Li, T.; Wang, L.; Du, Y.; Xie, S.; Yang, X.; Lian, F.; Zhou, Z.; Qian, C. Structural and mechanistic insights into UHRF1-mediated DNMT1 activation in the maintenance DNA methylation. Nucleic Acids Res. 2018, 46, 3218-3231. [CrossRef]

84. Schrödinger Maestro I Schrödinger. 2018. Available online: https://www.Schrödinger.com/materials-science (accessed on 27 January 2021).

85. Siu, S.W.I.; Pluhackova, K.; Böckmann, R.A. Optimization of the OPLS-AA force field for long hydrocarbons. J. Chem. Theory Comput. 2012, 39-40. [CrossRef] [PubMed]

86. Laskowski, R.A.; MacArthur, M.W.; Thornton, J.M. Procheck: Validation of Protein-Structure Coordinates; Wiley: Hoboken, NJ, USA, 2012.

87. Stewart, J.J.P. Optimization of parameters for semiempirical methods VI: More modifications to the NDDO approximations and re-optimization of parameters. J. Mol. Model. 2013, 19, 1-32. [CrossRef] [PubMed]

88. Assumpção, J.H.M.; Takeda, A.A.S.; Sforcin, J.M.; Rainho, C.A. Abstract A12: Brazilian Propolis as a Source of Novel DNA Methyltransferase Inhibitors: A Computer-Aided Discovery and in Vitro Approaches. Available online: https://clincancerres. aacrjournals.org/content/24/1_Supplement/A12 (accessed on 27 January 2021).

89. Tarcsay, Á.; Nyíri, K.; Keserú, G.M. Impact of lipophilic efficiency on compound quality. J. Med. Chem. 2012, 55, 1252-1260. [CrossRef] [PubMed]

90. Saha, B.; Thapa, R.; Chattopadhyay, K.K. Bandgap widening in highly conducting CdO thin film by Ti incorporation through radio frequency magnetron sputtering technique. Solid State Commun. 2008, 145, 33-37. [CrossRef]

91. Siemens Analytical X-Ray Instruments, Inc. Anal. Chem. 1990. [CrossRef]

92. Frisch, M.J.; Schlegel, H.B.; Scuseria, G.E.; Robb, M.A.; Cheeseman, J.R.; Scalmani, G.; Barone, V.; Mennucci, B.; Petersson, G.A.; Nakatsuji, H.; et al. Gaussian 16, Revision B.01; Gaussian, Inc.: Wallingford, CT, USA, 2013.

93. Friesner, R.A.; Banks, J.L.; Murphy, R.B.; Halgren, T.A.; Klicic, J.J.; Mainz, D.T.; Repasky, M.P.; Knoll, E.H.; Shelley, M.; Perry, J.K.; et al. Glide: A New Approach for Rapid, Accurate Docking and Scoring. 1. Method and Assessment of Docking Accuracy. J. Med. Chem. 2004, 47, 1739-1749. [CrossRef]

94. Tapp, H.S.; Kemsley, E.K. Notes on the practical utility of OPLS. TrAC Trends Anal. Chem. 2009, 28, 1322-1327. [CrossRef] 